\title{
Radicalization as Envious Militancy
}

\author{
Michael Moncrieffa \& Pierre Lienard ${ }^{b}$
}

Moncrieff was supported by the Swiss National Science Foundation [grant number 176781].

a Address: University of Geneva, Department of International Public Law \& International Organization, Global Studies Institute - Sciences II, Quai Ernest-Ansermet 3o, CH-211 Geneva 4, Email: michael.moncrieff@unige.ch

b Address: University of Nevada, Las Vegas, Department of Anthropology, 4505 S. Maryland Parkway, Box 455003, Las Vegas, NV 89154-5003, USA, Email: pierre.lienard@unlv.edu 


\begin{abstract}
Our model of radicalization articulates three readings of the phenomenon focusing on: (1) the rationality of the radicalized agent, (2) the prime mover explaining important facets of the phenomena, and (3) the strategic typification of concerns for the persuasion of wider audiences. We show that the rationality of the radicalized agent can be characterized as the calibration of specific parameters that determines a specific modality of thought that we capture in an abstract model we call the R.A.S.H. mentality - a model incorporating a particular risk preference and commitment to action which accounts for essential aspects of the radicalized mind. We propose further to reorient the causal arrow that has been privileged in the models of radicalization so far by linking radicalization to the experience of envy, an emotion that motivates individuals to monitor their surroundings, to assess the prosperity of others, and to seek the eradication of the status divergence. We conclude with the process of typification, which consists in widening the reach of concerns by simultaneously eliminating the particulars of the personal situation motivating the radicalized agent and evoking collective circumstance templates belonging to a repertoire of universal social forms.
\end{abstract}




\section{INTRODUCTION}

What is radicalization? What moves one to radicalize? Sageman ${ }^{1}$ laments the stagnation in terrorism studies seeing how after years of research the field is "no closer to answering the simple question of "What leads a person to turn to political violence?" Sageman attributes primarily such difficulties to the lack of empirical research and the inaccessibility of intelligence data. ${ }^{2}$

We propose another set of limiting issues, theoretical ones:

(1) the lack of a clear operational definition of the phenomenon that would be accepted by most experts (although most of us have many substantial intuitions about that phenomenon),

(2) the production of ad hoc descriptions and theoretical models designed to capture the minutiae of particular cases lumped into what seems arbitrary categories,

(3) the absence of a robust, unifying game-theoretical and evolutionary-informed functional characterization that would highlight an agent-level primum movens at the core of manifestations that we intuitively recognize as belonging to the same family of phenomena even though they might display apparently disparate surface properties,

(4) the reliance on little-analyzed, explicit utterances volunteered by militants to elaborate models of the process of radicalization, as if such verbalizations could be treated without much care as candid and truthful reflections of the motivational course followed in the first place, and

(5) the ideological and theoretical anchoring of much of the field of research on radicalization which has adopted, among other positions, a particular understanding of the agency of the radicalized agent, more responsive than agentive, ever so slightly or in one way or another privileging at its core a view of the perpetrator as a victim.

We begin our discussion by addressing our first question, what is radicalization? To define the boundaries of the phenomenon, we propose a game-theoretical model that elucidates the reranking of preferences characterizing radicalization. We argue that such reranking determines the particular rationality that governs the radicalized agent's attitude and commitment to strategic interactional social schemata, which accounts for that agent's motivational, and emotional transformation. Our game-theoretic model offers a plausible rationale for the radicalized agents' self- and other-regarding emotions ${ }^{3}$ reported in the literature including excitement/exhilaration, pride, shame, and contempt for oneself along with gratitude, contempt, and admiration for others.

For the second question (What moves individuals to radicalize?) we look to what, we propose, is more assuredly a primary: a specific emotion. Why? Tooby and Cosmides 4 argue that emotions have evolved for enhancing the response of the organism to evolutionary recurrent adaptive problems.5 Emotions facilitate the coordination of adaptive programs, prioritizing the functioning of some over other, given the task demand of the challenge faced, ${ }^{6}$ and thus consist in superordinate programs synchronizing the functioning of subprograms in charge of various functions such as perception, memory, motivations, categorization, prior probabilities updating and physiological reactions, that would be necessary for the deployment of adaptive responses.7 Those superordinate programs are associated with 'situation-detecting algorithms' that get evoked by proxies that were robustly associated with situations of adaptive challenges in our evolutionary 
past. ${ }^{8}$ As such, emotions would indeed constitute prime candidates for the position of Aristotelian unmoved movers. We argue that in the case of radicalization the prime mover is envy. 9 Furthermore, we hold that other emotions often mentioned in association with the phenomenon of radicalization are better conceptualized as later occurrences in the process of radicalization, downstream from the original envious motivation.

Our focus is on 'group' radicalization (i.e., radicalization that occurs in collectives often found in far right, far left, and jihadist movements). However, we argue that collective and individual radicalizations have much in common. To identify that similarity and explain why it typically does not transpire in the research on collective radicalization, we briefly touch upon the phenomena of lone shooters and other perpetrators of sectarian crimes. The connection between those types of radicalization has been made by other scholars but was not pursued to its requisite conclusions..$^{10}$

Whereas envy figures prominently in accounts of individual radicalization, it is absent in much of the expert literature on collective radicalization. In the latter, we find mentions of emotional experiences such as outrage and indignation, the desire for revenge, shame, guilt, and humiliation, which would occur in reaction to injustice, inequality, discrimination, ostracism, alienation, and personal failure. Indeed, the idea that grievances explain such emotions, which in turn play a critical role in radicalization is axiomatic to many theories of radicalization. We account for those affective manifestations in a different manner. Radicalized agents have an incentive to avoid the unmasking of their self-interested envious motives, which explains the systematic reframing of envious offensive impulses as defensive ones, a move that facilitates earning others' acquiescence and support while diffusing the responsibility for belligerent actions. The militants' explicit rationalizations obscure the motivations early at work in the process of radicalization. Rather than accurately reflecting the original motivations, such rationalizations might better be viewed as post-hoc justifications..$^{11}$

An oft-shared assumption by scholars studying radicalization is that it is possible to infer more or less directly the causes of such process from the rationalizations provided by radicalized individuals. Such a position rests on the ordinary intuition that the rationalization - or justification - of an action is typically its explanation. ${ }^{12}$ In every practical sense, for many of our social interactions, that equivalence works wonders: it allows us to assume that the agent had, as Davidson proposes, a primary reason for his action, which involves the coupling of a 'pro attitude toward actions of a certain kind' and the meta-representation 'that his action is of that type'. ${ }^{13}$ That is, the agent was competent for what it is that he was wishing, desiring, willing... Relying on such lightly analyzed, reasonably assumed intentionality of a postulated epistemically privileged agent is more than enough for most situations requiring social coordination, however, it should not be presumed that it shows us the way toward causal explanations with strong scientific validity.

Mercier and Sperber ${ }^{14}$ emphasize that reasons are for consumption: they have an audience. Our reasoning faculty would thus be for the generation of self-justification and persuasive arguments. 15 Were we to adopt the untenable position that the epistemicallyprivileged agent has full access to the minutiae of his intentionality and motivations and thus could produce reasons that reflect closely what caused him to make the decisions to act in a specific way, we would still have to contend with the hurdle that the primary reason that drove him to action would most probably not be the most persuasive or acceptable one to communicate to one's community of interpreters. In any case, 
explanations or justifications for actions and beliefs are unlikely to involve a process of retrieval that would retrace exactly, or even closely, the motivational mechanics that elicited those actions and beliefs. No cynicism in our model of agent need be permanently involved either. Rather, Mercier and Sperber ${ }^{16}$ propose that reasons are the products of an intuitive inference system, Reason, in charge of drawing intuitive conclusions about reasons, about their validity, their respective persuasion potential and the degree of confidence one might have in them. The greater share of that process is not conscious; the output of the various computations, the generated intuitions, is. This is not to say that an individual's volunteered reasons for militant engagement are haphazard or always inauthentic, but that such 'explanations' are unlikely to provide an accurate account of what has happened in the minds of radicalized individuals. Such reasons might better be viewed as post-hoc rationalizations rooted in the output of intuitive processes naturally biased in strategic ways.

\section{THE PROBLEM}

The self-inducement of Islamist recruits from the West epitomizes what we wish to explain. Between 2012 to 2016, approximately 4,000 citizens from EU Member States, mostly from large multicultural urban centers, made the decision to join militant groups in Syria. ${ }^{17}$ Those individuals joined the fight of their own volition and, in the process, exposed themselves to increased risks. What has instigated such abandonment of the safety of peaceful social transactions for risky bellicose actions? ${ }^{18}$ A forthright response would be the desire to challenge the status quo for social and/or material gains. The voluntary nature of their participation may appear perplexing still, given the inherent collective action problem involved - indeed, it would be far safer to abstain from participating while reaping the benefits of others' militancy since non-contribution could hardly be sanctioned. After all, we are talking of citizens of democratic welfare states who leave a generally easy life for some risky unknown and in some cases, for worse outcomes. ${ }^{19}$ Note though, that most people who might have felt tempted by such a 'radical move' at one point or another likely betted on the safer choice. Given the size of the pool of potential recruits in the source populations in question in Western Europe and the relatively small number of recruits they produced, it might very well be that most individuals who share some of their political views with our radicalized individuals were dissuaded to commit to more dramatic actions by their perception of the risk involved (and the costs it would entail in terms of standard of living, safety, family...) or, more simply, by the cost-free possibility of free-riding i.e., letting others take on the costs of pursuing objectives they might favor. What moves the radicalized individuals? How can we characterize their attitude?

\section{THE CHARACTERIZATION OF RADICALIZATION}

There does not seem to be widespread agreement on a specific acceptation of what radicalization would exactly be and entail. Mandel ${ }^{20}$ has proposed a broad definition of the concept of radicalization as "an increase in and/or reinforcing of extremism in the thinking, sentiments, and/or behavior of individuals and/or groups of individuals," a definition that leaves open important questions though. When exactly is someone to be considered 'radicalized?' What of the transition from extremist ideation to violent 
actions? Is there a necessary connection between those two steps, if they are to be understood as such?

Despite the criticisms, ${ }^{21}$ the term of radicalization has endured as a heuristic concept identifying a family of phenomena with some agreement among researchers. ${ }^{22}$ Divergences and disagreements emerge when the question of causation comes into play, ${ }^{23}$ with distinct models often focusing on whether specific political or ideological beliefs constitute prime explanantia of violent political action, ${ }^{24}$ or whether there is a necessary connection between cognitive radicalization (fostering extreme beliefs) and behavioral radicalization (acting out). ${ }^{25}$ Coolsaet ${ }^{26}$ has highlighted the concept's tumultuous political and academic history and the confusion that has surrounded its modelization, an ambiguity that has driven certain researchers to disuse the term. ${ }^{27}$

To characterize the phenomenon of radicalization, we trail a distinct route from the ones that were tracked previously. First, we offer a game-theoretical model of the radicalized agent's rational behavior. The characterization elucidates the peculiar rationality, encompassing a particular ranking of preferences, which determines the radicalized agent's attitude governing his strategic interactions with other social agents, in the pursuit of his high-priority social objectives. The model will throw in a new light some of the core findings of the literature on radicalization. Second, comes the concern about the motivation that spurs the agent to radicalizing. We commit ourselves to a methodological individualism approach that inverts the dominant orientation of the explanatory causal arrow found in Social Identity Theory and other affiliated models to draw the contours and the dispositional and behavioral implications of the motivational dynamic essential to the agent's radicalization. Our third analytical component, the process of typification, which we conceptualize as the implicit drive to frame the particulars of the agent's individual situation in collective terms, will reveal itself as the necessary entailment of the premier motivational logic.

\subsection{Game-theoretical model: R.A.S.H. preference ranking}

When thinking of radicalization, the purported quintessential examples quickly brought to mind implicate agents committed to suicide missions. Though a special case of a radicalized mind at work, the suicidal terrorist prototype has dominated our imaginary. It has also brought to the forefront the question of the rationality of such agents that would eagerly trade their life for political objectives, which, at times, even we, potentially on the receiving end of such acts, consider relatively minor ones, the costs incurred by the radicalized individual largely outweighing the extent of the actual harm done. ${ }^{28}$ The disconnect between affirmed political objectives and the perpetrated acts with the actual consequences that they have is too great. Could such a thorough abandon be rational? That general perspective has clouded the debates on the rationality of the decisions the radicalized mind makes once it fosters specific beliefs with their associated priors and abides by a particular preference ranking.

How can we capture the rationality of the radicalized agent as decision-maker pursuing specific objectives requiring some strategic coordination with other social agents? The question requires that we specify our understanding of rationality. For the present argument, we simply adopt the instrumental acceptation most readily defended by philosophers and economists: rationality entails the maximization of one's utility through one's actions, given the constraints one faces, the beliefs one has, and the 
preferences one harbors. Thus, in effect it means that an agent acts rationally if he selects the course of actions that he perceived to be the most beneficial to self and his objectives (i.e., he seeks to maximize his enlightened self-interest) at the lowest cost possible for himself, given the circumstances he faces. We rely on a game-theoretical modeling of interdependent decision-making to formalize the particular logic underpinning the typical decision-making of the radicalized mind maximizing its utility in strategic social interactions. Though the formal model is in no sense a mechanistic model and should be understood as a claim that the radicalized agent behaves as if his actions were determined by a set of ordered preferences over a set of behavioral choices, it permits to succinctly build the outline of the apparent rationality at stake, which is essentially defined by a strong commitment to act, and that, regardless of the exact explicit rationalizations the agent might publicize for such dedication. ${ }^{29}$ We propose that the best way to capture the decisional logics espoused by the radicalized individual in his strategic interactions is to conceptualize that agent as engaged in an $n$-person harmony game, as the latter was formalized in De Jaegher and Hoyer30 and De Jaeger. ${ }^{31}$

For the clarity of the logic at stake, let's take the simplified situation of a game of two players who have the option to choose between two strategies: cooperate or defect. Four potential payoffs determine the four-cell payoff-matrix: the punishment payoff (P) received when both agents jointly defect, the reward payoff $(\mathrm{R})$ earned when both agents cooperate, the sucker's payoff (S) when one agent cooperate and the other defect and, the mirroring case, the temptation payoff $(\mathrm{T})$ granted the defector when the other agent cooperates. $3^{2}$

Table 1. Basic game, payoff matrix

\begin{tabular}{ccc}
\hline $\begin{array}{c}\text { Player 1 } \\
\text { Player 2 }\end{array}$ & Cooperate & Defect \\
\hline Cooperate & R, R & S, T \\
Defect & T, S & P, P \\
\hline
\end{tabular}

According to De Jaegher \& Hoyer, the harmony game can be qualified thanks to two marginal payoff values: (R-T), the added payoff gained over the defection payoff when the other agent cooperates and (S-P), the added payoff of cooperating over the payoff of jointly defecting when the other agent defects. We are in a situation of harmony game when the conjoint inequalities $(\mathrm{R}-\mathrm{T})>0$ and $(\mathrm{S}-\mathrm{P})>0$ prevail, that is, when defection is always suboptimal in comparison to cooperation, given the expected cost incurred by the defector and when cooperation is always better, even when the other player defects. 33 This gives us the following preference ranking: $\mathrm{R}_{\text {eward }}>\mathrm{S}_{\text {ucker }}>\mathrm{T}_{\text {emptation }}>\mathrm{P}_{\text {unishment, }}$ that is, cooperation (of self and/or other) is always preferred over defection and joint cooperation assures the greater expected payoff. The $n$-person version of the game is essentially logically similar, but for the distinction that it involves agents playing harmony games with multiple partners (conjointly or sequentially). 34

How can that incentive structure be transposed in a terminology relevant to our case of concern? What does cooperate or defect represent in the context of political radicalization? We propose that 'cooperate' means the embrace of a commitment to act, hence the downplaying of the risk involved in the participation in comparison to the 
purported risk faced if the status quo prevails, while 'defection' means the opposite, the shying away from such commitment and its associated expected risk. The acronym R.A.S.H. captures succinctly the preference ranking of the harmony game $\left[\mathrm{R}_{\text {eward }}>\mathrm{S}_{\text {ucker }}\right.$ $\left.>\mathrm{T}_{\text {emptation }}>\mathrm{P}_{\text {unishment }}\right]$ reconceptualized in the radicalization context. Given the purported adverse odds faced, defection being a non-option, the payoff of rallying $\left(R_{\text {ally }}\right)$ is the greatest; the payoff of solo action $\left(A_{\text {ction }}\right)$ is the next best one, no matter what others decide, and, even if not oneself ( $S_{\text {kirting }}$ ), that someone do something is preferable to the status quo $\left(H_{\text {elplessness }}\right)$, which gives us the overall preference ranking $\left[\mathrm{R}_{\text {ally }}>\mathrm{A}_{\text {ction }}>\mathrm{S}_{\mathrm{kirting}}\right.$ $>\mathrm{H}_{\text {elplessness]. }}$.

\subsection{The affective experiences associated with R.A.S.H. mentality}

Concerns for the well-being of a collective are often adduced in the radicalized individuals' explicit rationalizations, which could lend us to think that altruistic motives, much more than enlightened self-interest, play a premier role in animating radicalization. We suspect that once again the evocation of such collective themes might be later elaborations, part and parcel of a-posteriori rationalizations. And, once again, those concerns could well be genuine and sincere, once the agent hit upon them as justifications of his intuitions about a perception of an adverse state of affair faced, but given the level of analysis we are focusing on at this point, that is of little consequence for our model. The R.A.S.H. model tells us where to look for ascertaining what might be at play at the core of the process of radicalization: utility maximization and expectation of social recognition benefits. Table 2 presents the next argument in a summary fashion.

Table 2. R.A.S.H.-predicted emotions

\begin{tabular}{lcc}
\hline Behavioral Choices & Self & Others \\
\hline Rally & Exhilaration & Gratitude \\
Action & Pride & Contempt \\
Skirting & Shame & Admiration \\
Helplessness & Self-contempt & Contempt \\
\hline
\end{tabular}

Emotions experienced by the agent, self- or other regarding, corresponding to their respective behavioral choice, given the agent's preference ranking

The self-interested agent has a strongly preferred objective. The adoption of the pursuit of that objective by others, i.e., their rallying, is particularly gratifying for the agent who feels grateful toward those equally contributing others. In other words, the agent is better able to maximize his utility (as manifested in his specific preference for a particular objective) thanks to the contribution of others to his chosen objective. The situation when the agent goes at it alone entails the emotions of pride for self and contempt for others that drive the expectations of a special social ranking of self, dominant and deserving, and of others, submissive and indebted. The choice of committing to act, no matter what others' choices might be, hence increasing the risks the agent faces, evokes a sense of superiority and deservedness in that agent and an expectation of the abasement of others that agent views as conceivably gaining from his action. A strong negative emotion downplays the attractiveness of skirting, while the requisite positive emotion toward contributing others, admiration, would inherently 
place the agent at a lower social standing, in a submissive position. Inaction means the further downgrading of agent and others to a level that evokes contempt.

The R.A.S.H.-predicted self- and other-regarding emotions experienced by the agent in the different behavioral choice situations is consonant with the findings made available in the literature. Excitement/exhilaration, 35 gratitude, 36 pride, 37 admiration, 38 contempt, 39 and shame 40 transpire as essential aspects of the experiences reported by radicalized individuals when they had to deal with those relevant behavioral choices we have highlighted above (cooperation, action alone, skirting, and general passivity).

\subsection{Evidence for the R.A.S.H. model}

Is there further evidence for the R.A.S.H. model in the literature on radicalization? Marsters ${ }^{41}$ provides linguistic evidence that could indirectly support our proposal. Marsters analyzes the discursive productions of two types of individuals engaging in hate speech whom she calls the Hunters, who have acted out, and the Howlers, who have not. Hunters would resort to using significantly more modal expressions and auxiliaries supporting the prediction of likely harm to self or in-group and expressing the inevitability of the elimination of the threat faced..$^{2}$ The linguistic productions of the Howlers are better qualified as expressions of outrage, with the relevant linguistic excesses involved in such expressions. 43 The R.A.S.H. model would predict that the public expressions of radicalized individuals should betray their indubitable commitment to the elimination of the proclaimed adversity: the threat faced should thus be dire, justifiably so that inaction would be foolish on one's part or anyone's part for that matter (i.e., the risk of inaction weighs more heavily than the risks associated with acting in the assessment). But dread should not come alone, certainty should be its necessary companion: the payoff of acting makes it all worthwhile (i.e., the benefit of acting significantly outweighs the benefit of inaction). A radicalized mind is certainly not a despondent mind. Note also, without any surprise there, that the combination of those two lines of pronouncements aligns well with our layman's intuitive understanding of radicalization as the manifestation of a strong unconditional contribution to the pursuit of a dangerous objective, married with a relative insensitivity to the significant level of potential risk involved and an inflated sense of agency. Kruglanski et al.44 have proposed the concept of motivational imbalance that identifies that moment when the radicalized individual reaches the point where doing something about a despised situation gets prioritized, becomes all encompassing, and crowds out other needs.

Additional linguistic evidence can be found in reports of studies and interviews of extremists. Saucier et al. analyzed extremist narratives from various sources and found the recurrent insistence on the risks of existential threats, the imperative need to act, and the affirmation of the efficiency of violent action. 45 Knight and colleagues, in their multiple-source-based (e.g., reports, news) case analysis of 40 individuals categorized as violent $\mathrm{v}$. nonviolent extremists, found that the violent activists were significantly more likely than their non-violent counterparts, to have signaled in their communications a concern for their personal responsibility to act. ${ }^{6}$ The themes of impending doom/crisis requiring action, and dutiful dedication are also quite prominent in interviews of radicalized individuals. 47

Those pronouncements, verbal markers and other linguistic expressions are the public face of the radicalization logic; their surface properties should not drive our immediate 
understanding of the phenomenon. $4^{8}$ Indeed, those manifestations give us access to important aspects characteristic of the radicalized agent's behavior and decision-making processes, but - it is our contention - indirectly so only. As we have highlighted above, those utterances make clear (for all, scholars as much as for their original intended audience), the essence of the motivational and interdependent logics to which the agents have bound themselves. Regardless of the actual paths that have led to their production, those utterances present a reasonable 49 - potentially inherently persuasive argumentative façade (i.e., the risky action is immediately justified) while they still betray or convey in an acceptable way5 the truthful motivational nugget at the heart of the rationalizations, the unwavering commitment to the elimination of the proclaimed adversity. Thus, we do not commit to any specific claims about the exact computational paths involving processes that could be described at a higher level of reality, such as selfdeception, genuine conviction, socially induced self-restraint, and so on, that might have brought a specific individual to commit in such a fashion (or, for that matter, in what proportion those processes, hence described, might have contributed to a particular outcome). On the other hand, we do propose that strategic, self-interested agents should be expected to display such typical behaviors, as they contribute to the generation of common knowledge - publicizing the core motivation animating the agent in a persuasion-aimed rationalization - which might lead to particular payoffs. In other words, whether an individual is cynical or not is of no concern to us here. ${ }^{1}$

\subsection{Motivational reading: the mainstream model}

Groups identity and concerns about social self/identity have played a central role in the mainstream model of radicalization. ${ }^{2}$ Since Tajfel's trailblazing work, Social Identity Theory (henceforth SIT) and later theoretical refinements (e.g., Self-Categorization Theory, henceforth SCT) have been prominent approaches in the research on radicalization. ${ }^{33}$ At the heart of the SIT model, and its extension SCT, is found the human propensity to categorize people into social groups, that categorization contributing an elemental share to the whole of social agents' compound identity. 54 That aspect of the selfconstruction, termed 'social identity', would thus be derived from one's group membership. 55 The activation of that feature of the self in social situations engages the agent in the comparison between his and other groups..$^{6}$ The agent's self-concept would be impacted by the perception of the status ranking of his group: lower status, lower selfimage and self-esteem; higher status, boosted self-image and self-esteem.57 Given that crucial link between self-concept, self-esteem and identity conferred by group membership, the upholding of the status of the group would be an important objective for social agents..$^{8}$ Thus, self-esteem, considering its commingling with social identity, would be a significant motivation to actively respond in specific ways to distressing evidence of the low social status of one's group, by either defecting to join another higher-status social unit or acting to change the disadvantageous terms of the comparison.59 In essence, a dissatisfactory social identity would be the source of powerful motivations behind great social upheavals and intergroup conflicts. ${ }^{60}$

SIT has inspired several causal models that have sought to explain radicalization. ${ }^{61}$ Uncertainty-identity theory, ${ }^{62}$ for instance, has proposed that social shocks and personal challenges generating uncertainty in individuals' lives could explain the motivation to affiliate with groups providing a strong sense of identity. Extremist groups would do just 
that, given their unambiguous ideologies, rigid leadership structure, and groupnormative behavioral demands. Thus, the more extreme the group, the more it would help to satisfy individual needs for certainty, structure, affiliation and identification. ${ }^{63}$

The family of theories to which belong the models broadly described above articulates in similar ways three primary propositions: (1) the self-concept is significantly constructed by group memberships; (2) the agent's intentionality and motivations are thus to some extent essentially determined by those memberships, and (3) the selfevaluation of one's esteem-worthiness, partially inferred from one's group affiliations, is at the core of intergroup dynamics as prime mover. However, along with Noranzayan et al.,64 we wonder whether conceptualizing the maximization of positive self-regard for its own sake as an agent's fundamental adaptive goal is not introducing a confusion between proximate and ultimate levels of analysis. Indeed, in the framework of an evolutionaryinformed functional perspective, we naturally puzzle over claims that place such a pursuit for its own sake at the heart of any explanatory model.65 That an organism feels good about oneself has been of little concern to nature, if we may express that in such an inelegant way. ${ }^{66}$

Instead of locating the initiation of the dynamic of radicalization in group-identity concerns and process of self-valuation, we look to what, we propose, is more assuredly a deeper cause: a specific emotion. Which of those evolved emotions would be at the initiation of the process of radicalization? Many models of radicalization highlight the role of social comparison, whether that is between self and other or between one's group and others'. However, it is usually coupled with the consequences that the evaluation of a negative differential of status between, say, self and other, triggers: self-deprecation, selfdespise, and shame, those purportedly being strong motivators to radicalize. Since Hoffer's landmark work, ${ }^{67}$ the usual mechanism proposed that would link shame and selfdeprecation to radicalization would basically be a sort of general reframing, a shedding of one's despised old self for a new proud and confident one that would typically be afforded by the adoption of an ideology promoted by religious or political organization. The transformation would involve a sacrifice of the self, a loss of one's 'individual distinctiveness,' through the dissolution into a collective whole. ${ }^{68}$ The transformation would explain some of the nihilistic tendencies (i.e., disregarding what is for what is sure to become) and a general future-orientation (i.e., betting on a glorious future) of the agents engaged on the path to radicalization. ${ }^{69} \mathrm{We}$ suspect that process could be explained differently, in terms of the specific modality of social coordination into militant groups, which would predict some of the specific rationalizations mentioned in those models of radicalization, such as the downplay of one's previous identity, the display of confidence in the success of the collective endeavor, or the being 'all-in'.70 Those could be conceptualized as an integral part of the expected signaling of commitment and dedication or the a-posteriori reasons provided for justifying one's involvement in the first place. We later develop further the question when we treat the problems of typification and collectivization and, later still, the issue of assessing the explicit reasons provided by (de)radicalized individuals. In any case, if indeed those signals and justifications are some of the necessary accompaniments to the emergence and the maintenance of militant groups, they would only be secondary manifestations and, once again, not prime movers at the root of the process of radicalization. 


\subsection{Unmoved mover}

Picturing some of the major constraints and conditions our ancestors faced in the Pleistocene environment, before the advent of more pronounced and stable social hierarchization, should help in the identification of the evolved emotion playing a crucial role in bringing an agent to radicalized. In comparison to our present conditions, the Paleolithic social world would have been smaller in scale, most ordinary interactions involving a definite pool of agents, a closed world of kin and kith of restricted ambit. Humanity relied on foraging; scarcity must have been the norm. Those foraging communities were socially lowly differentiated and technologically simple (i.e., with some specialization, all adults could manage the technology). Maintaining access to resources and people would have been critical, which would have been conducive to significant levels of agonistic interactions. But being able to benefit from others' social investments would have also been critical, while being deprived of support would have led to dramatic consequences. Given the benefit brought by cooperation, being regularly chosen as an exchange, alliance or coalitional partner would have been definitional of one's success in life too. That Paleolithic existence would have been about constant and careful oscillations between zero-sum and cooperative interactions, without much option to exit altogether the closed world one inhabited.

In such a world of constraints and scarcity, what if an individual significantly distinguishes him/herself in one way or another, by his success, his ability to acquire goods and partners, his reputation? What could this mean? His or her monopolizing of a greater share of the social benefits, investments or deference, resources, and other goods available in limited supply inherently suppresses the fitness of others. That zero-sum understanding of inequality is one of the hallmarks of our humanity. ${ }^{71}$ Such a disposition is none too efficient any longer, given the type of societies we dwell in, where non-zerosum interactions are more the norm than their negative counterparts; however, it must have been quite functional in our ancestral past. ${ }^{72}$ But the peculiar prosperity of an individual might not have just been computed in terms of fitness suppression in a competitive environment for scarce resources, it would have also been interpreted as evidence that such an individual might probably have benefited of particular advantages, making that agent a potentially dangerous competitor. The identification of those advantages would not have been easy; in the end what makes the difference between any two individuals: natural endowment, learned skills, luck, history...? To reverse-engineer one individual's success to try and find out what might have been decisive in it is a costly and imperfect endeavor, which, in any case, does not guarantee that the findings could be deployable by the discoverer (in the situation of natural endowment or a complex learned skill, for instance).73 In any case, the informational asymmetry between successful and scrutinizing agents is much too great right from the start. What simple option might there be to contain the risk afforded by the prosperous agent? Short of the elimination of that individual, the closest move would be to seek to eliminate his or her advantages or the gain that those advantages have brought him. 74

Which emotion would motivate individuals to monitor their social surrounding to assess the prosperity of agents and, when a significant difference is detected, would induce individuals to seek the elimination of the divergence? Envy, an evolved superordinate program in charge of motivating the agent to track advantages that other individuals have, and he does not, which could have fitness-suppressing consequences, 
and to do something about it. Schoeck seizes clearly what envy is in a non-computational psychological perspective: "the state of mind of a person who cannot bear someone else's being something, having a skill, possessing something or enjoying a reputation which he himself lacks, and who will therefore rejoice should the other lose his asset, although that loss will not mean his own gain". 75 Vindictiveness toward the other who displays particular assets (personal, social or material) and the desire to destroy those assets and advantages are the experiences at the heart of the emotion..$^{76}$ Thus, we are using envy technically with that specific understanding in mind: not for the felt qualia (whatever it may exactly be) but as identifying the functional property of the emotion, as motivation supporting the impulse to destroy or eliminate the perceived advantage, and, if it applies, to hate the target.77 Envy is thus a powerful motivator which has for objective the neutralization of the potentially fitness-suppressing advantages others have. It is a negative impulse, primarily motivating the agent to commit to offensive, and not defensive social strategies (i.e., to actively seek the elimination of the advantage), hence it is perceived by others as immediately threatening and socially disruptive. 78

Schoeck79 proposes that a natural disposition to experience - and to be afraid of being the target of - envy is operational for containing the deployment of socially exploitative treatment, and, more broadly, assessing the judiciousness and fairness of decisions and behaviors of others, as much as of the self. ${ }^{80}$ If so, the proposal gives us some depth into the rationale of the motivational impact of the negative emotion: envy is about deterrence, and certainly not about an attempt at negotiating better transactional terms between envious and envied agents. ${ }^{81}$ Indeed, a concern for envy brings the shadow of the future into our decisions. The concern for socially disruptive threat of aggression targeted at individuals that have 'strayed' from the expected and accepted norm (of success, of performance, of abilities...), making it harder for others to achieve and perform ordinarily, explains much of what anthropologists have - probably inappropriately ${ }^{82}$ called 'levelling mechanisms.' The problem is not to guarantee equality between social agents, but to maintain the illusion of such, thus buffering successful agents from envy. The envy-motivated deception amounts to a levelling to the postulated lowest common denominator, erasing as much as possible the obviousness of the inescapable differences that exist between agents. The concern is about conflict, not inequality; the systematically successful hunter being prohibited to brag about his success is still known as such and more than likely gets some benefits from that recognition. In terms closer to our social reality, we could say that he accepts a rather high visible taxation for the sake of some relative peace of mind. 83

In light of the available evidence in the literature, it is our contention that what is at the origination of the process of radicalization is that frustration that involves the perception of some inequality in the distribution of social, reputational, physical assets, ${ }^{84}$ interpreted as the consequence of foul play, the enjoyment of undisclosed (and unearned?!) advantages, or the outcome of the control and exercise of unmatchable physical, psychological, social assets. ${ }^{85}$ Note also the important following caveat: the generation of envy is not to be equivalenced to the detection of actual, unbearable inequalities by the agent; very little perceived discrepancies are enough to fuel envy and the motivation to eliminate the threat of the successful social competitor. ${ }^{86}$ The (un)acceptability of a social distinction rests in the eyes of the beholder; "there are no objective criteria for what it is that stimulates envy". .87 


\section{FROM OFFENSE TO DEFENSE - THE MOVE FROM SELF- TO COLLECTIVE INTEREST}

\subsection{Invidia beckons... to little avail.}

Do we find evidence of a systematic connection between envy and extremist violence? The literature on lone shooters seems to indicate so. The following examples provided by Langman 88 illustrates how envy often figures prominently in school shooters' motivations: "oh the happiness I could have had mingling among you hedonists, being counted as one of you" 89 and "I want to be something I can never be. I try so hard every day. But in the end, I hate myself for what I've become". ${ }^{\circ 0}$ Klebold, one of the Columbine High School shooters, was not socially isolated, teased or bullied, but, was liked and involved in social activities. Yet, Klebold's rambling journal entries also underscore how thoroughly envy urged him on. ${ }^{11}$ At times, perpetrators are self-aware enough to fully acknowledge having been motivated by envy. ${ }^{22}$ In such clear cases, the violent actions are explicitly aimed at eliminating other social competitors' advantages, by pursuing an alternative path of reputation enhancement to the usual routes available in school settings. As Langman notes: "[the shooters] did not simply get a kick out of explosions or shoot-outs in movies and games; they learned that violence enhances the social standing of males" and thus "used violence to enhance [their] status". 93

In the midst of other motivators, envy has also been identified as one motivation behind some individual or collective violence outside of educational settings, including mass murders, hate crimes and other racist violence. 94 Envy appears to lead to an increase in the frequency of hate crimes. 95 Greater parity between black and white incomes, that is, in the specific context studied by Gale et al.,96 an increase in black household incomes relative to that of white households, was associated with higher white-on-black hate crimes, while the overall crime rate went down. Qualitative research has also found envy to be involved in racist violence, with one article noting "both shame and rage are dangerously present in perceptions of Asians as powerful and successful, and thus objects of envy [...]". .97 Fiske, 98 too, makes a strong case for the role of envy in motivating violence against members of successful entrepreneurial ethnic groups.

Envy is sometimes mentioned in the literature on terrorism and violent extremism, 99 but rarely as prime mover in isolation from other emotions. Cottee ${ }^{100}$ somewhat departs from the general trend by briefly insisting on the potentially central contributing role envy could have in incel-inspired terrorism. Incel refers to an online subculture promoted by men who, incapable of matching the demands of the mating market, find themselves stuck into involuntary celibacy. ${ }^{101}$ Indeed, posts on internet forums such as the following one illuminate the motivational part envy plays in incel groups dynamics and in the radicalization of some of their members: "Incels' see another side to humanity that the socially privileged are blind to". ${ }^{102}$

Although the scholarly focus seems to be more surely grabbed by hints of emotions such as shame, humiliation and indignation, ${ }^{103}$ envy appears to creep back in, here and there, as in the analysis of the verbal productions of the perpetrators of such violence as described above. Why such a systematic downplaying of envy? Why the privileging of 'defensive' emotions (e.g., humiliation, indignation) over an 'offensive' one (i.e., envy)? We argue below that the deemphasizing of the role of envy in radicalization studies might be traced to three main reasons: the very nature of the emotion prompting its 
concealment, a researchers-shared assumption about the conceptualization of the relationship between agency and structure, and the strong intuitiveness of the retaliatory action template.

\subsection{The peril of unmasked envy}

The experience of envy is removed from the occurrence of a provocation ${ }^{104}$ and the intentions and behaviors that it generates are constitutionally hostile, the envy prompting spiteful actions aimed at reducing the welfare of the envied. Being unprovoked, the envymotivated attack is regarded - before all else - as indefensible.105 It has the additional drawback of lending itself to being diagnosed by onlookers as indication of the envious agent's readiness to victimize others wrongfully, a capriciousness inherently threatening for third-party agents. Not surprisingly, such an attack is bound to elicit a strong moral condemnation. ${ }^{106}$ Furthermore, the envious agent's obvious disregard for potential gains and steep discount of likely welfare costs, so long as it decreases the target's welfare, communicate traits that are unwanted in social partners. ${ }^{107}$ Those attitudes and decision choices typical of the envier may also signal the agent lacks genuine moral restraints, thus calling into question the envier's trustworthiness. ${ }^{108}$

People go to great lengths to avoid being the target of envy given the threat it poses. 109 Potential cooperators should be weary of escalating their risks of being the object of envy by associating too closely with individuals apparently prone to experiencing that destructive emotion. Such impulsive social agents should also be judged as less reliable, which would clearly mark them as improbable partner choices, given the increase exposure to defection and cheating afforded by one's association with them.110

Silver and Sabini ${ }^{111}$ also see envy as harmful to moral reputation, but they add the possible injure to social value, which, according to them, would make that emotion 'doubly damaging' to the envier if unmasked. Indeed, envy discloses more than what its experiencer would want to, as it indirectly signals that the coveted is not owned. That information devaluates how desirable a partner the envier is, which, in turn, drives social agents to downregulate their inclination to tradeoff some of their welfare for that individual's. ${ }^{112}$ Given that social shunning involved significant fitness costs throughout human evolutionary history, we should expect strong motivations to address the threat of social devaluation, ${ }^{113}$ hence the proneness to conceal the envious motives behind one's decisions and actions. Indeed, enviers typically hide the experience of the emotion from others ${ }^{114}$ and envy lacks a distinct facial expression or bodily display, ${ }^{115}$ which facilitates concealment.

Given the risk unmasked envy affords, we should thus expect the reasons and justifications presented in accounts of radicalization to be modified in strategic ways to avoid detection. Cohen-Charash ${ }^{116}$ notes that, rather than acknowledging that envy explain their behavior, individuals systematically reason that unfairness explains their hostility. Other emotions such as humiliation, a sense of injustice, and moral outrage are also often evoked. Those emotions frame the situation as one of a justified response to a previously imposed cost by others. If our model is accurate, we should indeed expect that those specific emotional motivations (and their associated cognitive templates) should be the ones most often volunteered by radicalized individuals as explanation for their extreme decisions and actions. 


\subsection{Offense v. defense}

To reduce the risk afforded by the unmasking of envious motives, the envier must reframe how others perceive his actions. There are two primary ways that individuals could make motivations and actions appear less self-interested and selfish. The first involves the framing of the aggressive impulse as defensive rather than offensive. ${ }^{117}$ The other rests on the diffusion of responsibility within a plurality of individuals. ${ }^{118}$ That latter path will be discussed later in the article under the 'process of typification.'

Scholars have advanced persuasive game theoretic models of the strategic choices, preference-rankings, and payoffs of defense- and offense-motivated aggression.119 Offense likely generates nonpublic private goods, while defense, public goods. ${ }^{120}$ Indeed, successful offensive actions typically confer rewards to those who partake, such as access to resources, status increases via the elimination of competitors, and reproductive access. ${ }^{121}$ On the other hand, defensive actions typically provide collective benefits such as the holding of territory and group safety, which are not easily excludable goods. This explains why the willingness to engage in offensive aggression is primarily predicted by the perception of potential personal rewards to be had, whereas the inclination to participate in defensive actions, by the perception of likely group benefits. ${ }^{122}$ These differences in relative payoffs probably account for why offensive aggression is much harder to justify than defensive aggression.

Differences in the payoffs of offensive and defensive aggression have probably shaped proximate psychological adaptations in predictable ways. Attack and defense should therefore activate different motivational and biobehavioral systems. ${ }^{123}$ De Dreu and Gross ${ }^{124}$ argue that offense should be associated with the activation of neural circuitries involved in the processing of rewards. If radicalized individuals are motivated by selfinterest, then we should expect them to report pleasurable feelings (e.g., enjoyment, excitement). Indeed, scholars report that radicalized individuals regularly allude to the feeling of excitement and the drive to look for adventure. ${ }^{125}$ A meta-analysis of radicalization risk factors found risk-taking and thrill-seeking to be strongly associated with violent engagement. ${ }^{126}$ Such findings support the proposition that radicalized individuals are motivated by the prospect of personal gains that could be obtained from offensive actions. ${ }^{127}$ Such evidence conflicts with the reasons most often provided to justify the individual's radicalized beliefs and militant actions. Ajil has noted the care that some radicalized individuals take to downplay the reporting of excitement: "It's all very exciting, being in these situations. They're incredible sometimes. But it shouldn't be violence just for the sake of it. [...] If you are just guided by your own desires, it merely becomes another manifestation of self-centeredness". ${ }^{128}$ Emotions that signal selfinterest should not be given as the reasons used to justify militant actions. Such reasons should instead focus on reframing offensive motivations in terms of defense. The evocation of social grievances and associated emotional templates is well-suited for manipulating others into accepting the legitimacy of one's decisions and actions.

\subsection{Strong intuitions}

Direct references to envy are few and far between in the justifications offered by radicalized individuals involved in political or religious activism. We saw probably why that is above. But why would mentions of envy as a causal factor be so very rarely found 
in the expert literature?129 Either one of two intertwined biases could be at work here, that can be traced to an ideological-theoretical position for one and to intuitions, for the other. The former centers on the idea of the perpetrator-as-victim, that is, the extremist agent's behavior would be best explained by the injustice he has endured: it is the by-product of an oppressive, unjust, and discriminatory system. ${ }^{130}$ That ideological position partially rests on a particular theoretical understanding of the relationship between individual agency and system. Social pathologies involving dramatically deviant behaviors would be reflections of structural constraints. Thus, the elimination of deviance requires a systemic approach, i.e., targeting the extirpation of what is perceived to make injustice endure. The latter bias, intuitive, might flow from our greater ease to understand and accept retaliation as a justification for the perpetration of violent acts, which we discuss further below.

Although envy is absent of much of the expert literature, we often find mentions of other emotional experiences such as outrage and indignation, ${ }^{131}$ desire for revenge, ${ }^{132}$ the longing for excitement, ${ }^{133}$ shame, guilt, and humiliation. ${ }^{134}$ These emotions and experiences would be reactions to injustice, inequality, discrimination, ostracism, alienation, and personal failure.135 In these models of radicalization, the broadlyprivileged dominant causal arrow goes from social environment to agents, from 'provocations' to 'expected responses', hence, radicalization would find its origin, and in a certain sense, its justification and explanation in an uncompromising externality.

The idea that grievances explain such emotions, which would in turn play a critical role in radicalization is indeed axiomatic to many theories of radicalization. ${ }^{136}$ From the acknowledgement that perpetrators systematically mention grievances (e.g., state aggression, collective humiliation, perceived threats) at the source of their belligerence, ${ }^{137}$ the conclusion is regularly drawn that such justifications probably constitute appropriate explanations for the radicalization in the first place. Webber and Kruglanski ${ }^{138}$ provide a good example (if quite insightful) of that tendency. They acknowledge how salient collective disenfranchisement, victimization, and discrimination are among the sources of discontentment and frustration mentioned in the testimony of perpetrators and ascribe a prominent explanatory role in their model to the psychological consequences of those experiences of collective injustice along those of more personal failures and victimization. ${ }^{139}$ According to their model, humiliation (collective as much as individual) and shame generate a loss of social significance, which in turn motivates the affected individuals to fulfil their desire to matter and boost their self-respect.140 In the case of violent extremism, that quest for personal significance becomes overly dominant, eradicating the psychological restraints on extreme behaviors that other competing needs would ordinarily exert. ${ }^{141}$ In such conditions of psychological imbalance, individuals are more receptive to narratives tying violence to the attainment of significance and the conferment of social rewards such as status and honor.142 Though Webber and Kruglanski ${ }^{143}$ acknowledge that self-esteem (and, sometimes, personal failures) mediates the loss of significance, they essentially conceptualize radicalization as a reaction to perceived external 'provocations'; thus the agency of the perpetrators is once more fundamentally viewed as primarily responsive.

To reiterate our position made clear above, we argue, with several other researchers, that rather than causing one to radicalize, grievances probably serve to explain and justify one's actions. There is some evidence that grievances may serve a justificatory rather than causal role in radicalization. It has been noticed that grievance complaints were 
remarkably absent from the accounts of individuals' early decisions to join radicalized groups. Ilardi ${ }^{144}$ proposes that radical Islamists "were not motivated to join like-minded individuals or groups for the purpose of correcting perceived social or political wrongs perpetrated against the global Islamic community [and that] perceptions of Islamic victimization emerged as a product of the radicalization process, rather than [served] as a driver of it."

The latter bias, attributable to the strength of intuitions, might flow from our greater ease to understand and accept retaliation as a justification for the perpetration of violent acts. The RETALIATION conceptual template comes equipped with built-in intuitions about the rationale for action, the risk of omission, the inherent benefits of the negative reciprocity, and the praiseworthiness, or, at the very least, the acceptability of the aggression in return. In short, RETALIATION provides an immediate grasp of the incentives accounting for the observed behavior. Unprovoked aggression is not as immediate to grasp, given the risk involved in the violent behavior. It requires more informational search to assess what the objective of the perpetrator might be - assertion of dominance, signal of formidability, exploitation... - and is inherently much harder to legitimate. Whatever the case may be in specific instances, both biases lead to explanations that mirror the explicit justifications regularly volunteered by perpetrators. Their actions were defensive only; they were provoked.

To understand why the reporting of grievances is typically paired with emotions such as outrage, humiliation, and ressentiment, it may be useful to consider how such emotions may help to justify violent actions. Emotions are fine-tuned to detect and respond to classes of specific situations. ${ }^{145}$ Specific social emotions evolved to recognize and respond to prototypical social situations. ${ }^{146}$ Those games which played out repeatedly throughout evolutionary history are immediately recognizable and can be thought of as templates pertaining to a grammar of universal social forms. Specific cues systematically associated with typical situations serve as input to proximate computational systems, which gives rise to particular emotions. The systematic association between situational templates and particular emotions allows us to intuitively grasp what is at play when another person tells us that she feels guilty, angry, or outraged. We all have access to the corresponding situational templates, the typical motivational and behavioral consequences those emotions evoke, and a grasp of their qualia. The mention of a specific emotion precisely communicates the chosen frame interpreting a situation, providing immediate access to a large reservoir of intuitions. ${ }^{147}$ Conveying an emotion such as outrage might contribute effectively to that objective by manipulating the interpretive frame for making sense of the perpetrated actions, hence preparing the ground for reasonable justifications relying on situational templates deflecting responsibility away from the agent. As noted previously, harm is more justifiable when it is motivated by defense. We should therefore expect the envier to provide reasons which cue the inputs of emotions designed to motivate agents to respond to harmful actions of others. Humiliation is a particular good example of that process of deflection. Scholars studying violent extremism have ascribed a prominent role to humiliation in the radicalization process. ${ }^{148}$ Elison and Harter ${ }^{149}$ conceptualize humiliation as an event where an individual experiences a highly intense emotional reaction to having been lowered in the eyes of others because of someone else's purposeful and hostile actions. Typical reactions to humiliation include violent ideation, and (desire of) revenge or retaliation. ${ }^{150}$ Gilbert ${ }^{151}$ notes that while humiliation has features in common with shame, it is nevertheless distinct in that it involves an external 
attribution (i.e., one is not the cause of the devaluing circumstance), a liable hostile other (as opposed to a guilty or ashamed self), a feeling of unfairness, i.e., that the circumstances do not justify the treatment (e.g., one does not deserve to be treated this way), and a motivation to look for revenge or retaliation (even if not acted upon). Humiliation thus immediately evokes in others a template that someone else's purposeful and hostile actions are to blame for any subsequent harmful actions by the actor. That humiliation is commonly used to strategically reframe offense as defense rather than actually cause violence, may account for Ginges and Atrans's ${ }^{152}$ null finding that the experience of humiliation did not contribute to political violence.

For the general model briefly sketched above to be complete, an altruistic element needs to be added to the grievance argument. Militants regularly frame violent actions as necessary for the defense of collective goods, values, and safety. Bosi and Della Porta, 153 for instance, observe that the mobilization into armed groups and the commitment to violence are most ordinarily justified by the need to defend one's community: "What upset me was to see that the people were incapable of defending their own country. [...] I was a young man and to me, I really had that kind of value of the man that had to go fight, to defend his country and his values. The fact that you leave your wars and countries is what forces people who are not even from here, not from this country or religion, such as me, to go fight there". ${ }^{154}$ Scholars note how some militants also saw "jihad as an individual obligation of the highest order. Seen within the context of self-defense, the virtues of jihad were considered self-evident and beyond question. One individual... explained that he [recruits fighters] 'because it doesn't make sense not to go . . . you have to defend your family, you have to defend your friends, and your fellow people, to protect them from occupation, from wrong"'. ${ }^{155}$ The prominence of such justifications in the interviews of militants and other radicalized individuals have convinced scholars that such altruistic motives must play a central role in the explanation of radicalization. ${ }^{156}$ Why do we find such a systematic insistence on a collective duty in the account of radicalized individuals?

\subsection{The process of typification: the diffusion of responsibility and the reframing as collective projects}

We operationalize the concept of typification as the modeling of a personal plight as a particular case (token) of a prototypical collective situation (type) at the heart of the persuasion process attempting to diffuse responsibility. Seeking out partners to reduce the costs afforded by envy and spite might explain the data presented in the causal models inspired by SIT that seek to explain radicalization. ${ }^{157}$ Rather than identity being a cause of radicalization, it may very well be that aligning with others who might share common envious interests makes good strategic logic. The extent to which one can align with others to pursue envious goals, helps to diffuse responsibility 158 while it increases one's relative power and formidability. 159 The idea that the possibility of diffusing responsibility might underly one's willingness to engage in spiteful actions is supported by recent research showing how peer networks play a role in increasing violent intentions. Kaczkowski et al. ${ }^{160}$ found that violent extremist intentions were increased when it was perceived that one's peers had similar attitudes; however, having a more diverse social network reduced such intentions. Interestingly, the fact that 'lone wolves,' those who attack without the direct support of others, are nevertheless typically 'connected' in some way to a community speaks to the facilitating role that the perceived diffusion of responsibility 
plays in the acting out of radicalized individuals. ${ }^{161}$ The fundamental difference between loners and militants belonging to a collective might just be that the former have not actually found an active collective, ready to act in a concerted fashion. There is evidence indeed that 'loners' attempt to anchor their acts into imagined genealogies of perpetrators. ${ }^{162}$

Coordinating which side to take in conflicts may well be a primary function of moral reasoning and outrage. ${ }^{163}$ Attacks directed at a set of agents that share some common property (i.e., identity), evoke moral outrage and condemnation among that set of agents because such attacks are diagnostic of one's risk of being harmed in the future. 164 Humiliation, injustice, and outrage are thus usually cast not only as affecting the individual, but the collective as a whole. Such reframing, hiding brute self-interest behind collective pretext, makes it easier to manipulate others into believing that violent actions are necessary and justified. Indeed, radicalized individuals often appeal to others not with their own personal accounts of victimization, but with collective accounts of harms caused by an enemy. Indeed, numerous examples of accounts of collective humiliation and harm are found in the literature on radicalization. ${ }^{165}$ One particularly insightful example of how framing violent actions as a response to collective harm can reduce culpability is found in the following account from a jihadi militant: "How agonizing is it to see the land of Muslims taken by the Monsters of Zion and the Crusades? How many Muslim states have been attacked and occupied by those envious parties? [...] And look at the liters of blood being poured out by those Dracula monsters. Those facts are more than enough to explain the fardhu 'ain (foremost obligation) nature of jihad". ${ }^{166}$ The leader of Al-Qaeda, Osama Bin Laden, also regularly appealed to collective moral justifications for his group's violence "citing the innocence, undue suffering, and equivalence among martyred Muslims throughout history, including [Al-Qaeda] mujahideen". ${ }^{167}$

\subsection{Counter-reasons unveil self-interest and other R.A.S.H. attitudes}

If our logic is accurate, we should expect counter-reasons of a very specific nature in the narratives of disengaged and deradicalized individuals. Those counter-reasons should include references to emotional experiences that indirectly highlight what probably were the motivations and emotions that determined the experiences of the radicalized individual in the first place. For instance, those individuals no longer locked into the R.A.S.H. rationality should privilege allusions to emotional experiences of opposite valance and arousal, such as boredom and censure, over the mentions of emotions such as exhilaration and gratitude (greeting the rally behavioral choice in the R.A.S.H. model) and pride and contempt (greeting the action behavioral choice). Those deradicalized individuals have shifted to another preference ranking as they are now playing a different 'game', a fact that should be reflected in their reasoning. Individuals who still reason within the context of the R.A.S.H. rationality but are no longer acting should now view themselves in a position of skirting or helplessness. These individuals should thus be more likely to report feelings associated with the emotions of shame and admiration or self-/other-regarding contempt, respectively.

The literature on disengagement and deradicalization provides preliminary evidence for such specific counter-reasoning and the R.A.S.H.-predicted emotions that should follow. Unmet expectations that resulted in disillusionment and disappointment (i.e., with group actions and strategies, members and leaders, and day-to-day tasks) are among 
the most commonly reported reasons offered by disengaged/deradicalized terrorists. ${ }^{168}$ The disappointment often signals that the expectation of further exhilarating experiences was not met any longer: "Life was starting to get a bit monotonous for me. And so I decided I wanted out. [...] Listen, it's not that I had any kind of ideological issues or anything like that. I just thought I was wasting my time [...]". ${ }^{169}$ That such selfish reasons only become apparent in militant narratives post-radicalization is noteworthy. Such evidence weighs strongly against an altruistic reading of the phenomenon. Gratitude for the actions of others gets replaced by the venting of censure and criticism of leaders, "[...] well, who's in charge here? That is when, one way or another, you first start to think about the idea of cutting loose, you know? [...] Until then, everything was absolutely unquestionable, ${ }^{170}$ and of members and group, "Shit, man, if people ever found out what ETA is really like, they would kick the living shit out of us and tell us to get lost and go fuck ourselves and I really mean that". ${ }^{171}$ Moving down our list of R.A.S.H.-predicted emotions we find that those emotions corresponding to the action behavioral choice, selfpride and contempt for those who skirted contributing, are also reflected in the thoughts of those post-radicalization: "I didn't want to have a bad opinion of people. [I got] tired of judging everyone but myself... It affected everything in my life in a negative way". ${ }^{172}$

Emotions that correspond to skirting, notably shame and admiration, seem to be present in those disengaging (but probably still reasoning within the R.A.S.H. logic) as in the following reflection by an Islamist illustrates: "My stomach told me this was the right thing, the only thing, to do. And yet I felt awful and heavy with guilt. I thought about Hakim, about how as a child he had given me money for candy. I thought about the Uzis. I thought about the 1.6 billion Muslims around the world who felt humiliated by the failure of the Muslim world and the arrogance of the West. I thought about all these things because I felt them deeply, and knew that Hakim, Amin, Yasin, and Tarek all felt them deeply as well. So I didn't blame them for who they were, or for what they were doing. But I needed to protect my family and myself, and I had run out of options". ${ }^{173}$ The emotions associated with the helplessness behavioral choice are also reported in the literature as the following example highlights: "[...] I feel such a distance to violence altogether that sometimes I feel castrated". ${ }^{174}$

The recalibration of the risk perception is also noteworthy in such narratives. For instance, once previously suppressed, the expression of fear creeps back in as the individual reassess the risks faced: "I had this really, really bad experience and the truth is that it scared the shit out of me. [...] bit by bit, this fear was creeping through me [...] The fear was in me and so I left". ${ }^{175}$

\subsection{Questioning the role of beliefs, values, and ideologies}

Some scholars have focused on the adoption of beliefs, values, and ideologies - sets of beliefs and values - as being key to understanding why an individual would become radicalized to the point of engaging in extreme and violent action for a collective. The 'devoted actor' hypothesis proposes that militant actors are motivated by their adherence to sacred and transcendent values. ${ }^{176}$ The actions of 'devoted actors' are not governed by typical cost/benefit, i.e., 'rational', calculations. Rather, militants would be mobilized by sacred group-held values, regardless of the potentially severe risks and/or the lack of rewards involved in their defense. ${ }^{177}$ Atran ${ }^{178}$ notes, terrorists "are motivated not by personal comfort or immediate gain but rather by religious or ideological conviction and 
zeal" and that "recruitment to [militant] organizations is more ideologically driven than grievance-driven." Research on militants supports the fact that many hold strong religious or ideological convictions. ${ }^{179}$ That such convictions serve as input to the computation that has for output radicalized attitudes, beliefs and behaviors could be defended. In our argument, such non-negotiable values and beliefs do not; they are found attractive in a specific socio-cultural context, and thusly adopted, because they match some of the intuitive output of the radicalizing or radicalized mind. They probably do not generate the radicalization in the first place and their lasting success is to be explained by the rich background of intuitions they meet, repeatedly activate and eventually systematically associate with. Thus, such beliefs and values would not be effective thanks to their specific explicit content per se, but because, as abridged informational structures that have come to condense essential aspects of generic social situations; they evoke prototypical templates pertaining to a grammar of universal social forms.

Scholars have questioned the strength and causal order of the adoption of extreme values or ideologies preceding radicalization. ${ }^{180}$ As we have alluded to above, empirical research suggests that knowledge of and commitment to extremist ideology often develops after an individual joins a group of radicalized militants. ${ }^{181}$ Radicalized neojihadi terrorists are noted as lacking a well-defined ideology and having an elementary understanding of Islam. ${ }^{182}$ A far-right militant insisted that ideology played an insignificant role in motivating her involvement but instead it equipped her "to demonstrate [her] knowledge [in order to] impress others". ${ }^{183}$ A former Neo-Nazi recalled that ideology was not a primary cause of his radicalization and "what mattered to [him] was that [he] would get a chance to participate in a real fight and kill the enemy" ${ }^{184} \mathrm{He}$ followed up by saying that ideology is "just an excuse" for violence and "[others] become extremists - Nazis or join al-Qaeda - for the sake of justification." Radicalized members of the IRA reported not knowing the political reasons for which they began fighting, calling into question the role of political ideology in radicalization..$^{185}$

Ideological change is also not a pre-requisite nor associated with disengagement from terrorist groups. ${ }^{186}$ Despite their disengagement, individuals often continue to harbor radical beliefs and ideology. ${ }^{187}$ This could suggest that ideology might not be playing a premier role in the radicalization process. One reason ideological 'packages' might be readily adopted by followers after being radicalized might reside in the fact that they provide 'ready-made' sound justifications for violent actions. Such findings challenge the idea that disengagement needs to be preceded by a loss of faith in the ideology supposedly underpinning the radicalized behavior. ${ }^{188}$ Note also that radicalized individuals have been known to switch from one hostile ideology to another, even seemingly incompatible ones (e.g., from far left- to right-wing extremism). ${ }^{189}$ In some of these instances it is clear that the decision to jump ship was influenced by the perception of the increasing costs and decreasing rewards of a specific membership. The late onset of ideological knowledge and its irrelevance to disengagement and group migration militate against ascribing an essential causal role to ideology in the process of radicalization.

We are far from the first ones to propose that ideology serves as post-hoc justification for one's willingness to engage in violence rather than a cause of violence, per se. ${ }^{190} \mathrm{We}$ wish to argue yet a stronger claim that most reasons volunteered by agents for explaining their radicalization should be viewed skeptically. Too often the level of analytical reduction is too shallow to identify both the informational input and the structure of the 
processing mechanisms involved that have led to the unfolding of specific action programs giving rise to the behaviors considered the hallmarks of radicalization.

\section{DISCUSSION}

What can we conclude from the R.A.S.H. model, its primum movens, and the attitudinal and emotional redescriptions associated with the dramatic transformation of a radicalized agent's behavior? The game-theoretical modeling of interdependent decision-making helped in the formalization of the specific logic underpinning essential and typical aspects of the radicalized mind's decision-making. The R.A.S.H. preference ranking that emerges from our analysis may help to resolve long-standing debates about the distinction between two purported forms of radicalization that came to be called cognitive (still fostering ideas only) and behavioral (now acting on them) radicalizations. Fostering extreme ideas and reasonably justifying them are not sufficient evidence to ascertain whether one is radicalized or even on one's way to being radicalized. Publicly stated reasons and the process of radicalization are probably dimensions in an orthogonal relationship, so to speak.

Following Davidson's position, ${ }^{191}$ while the acceptance of the reasons granted on the basis of a reasonably assumed efficient intentionality is more than enough for most situations requiring social coordination, it should not be presumed that it shows us the way toward valid causal explanations. This is not to say that reasons and justifications should carry no weight at all, just that we do need to be cautious when assessing such statements. For instance, as we have briefly shown, the reasoning about envy-inspired actions previously perpetrated by deradicalized agents should betray their move to a new rationality and preference ranking. The development of linguistic diagnostic tools might allow law enforcement to detect subtle differences in the deployment of reasons and justifications that could help distinguish between individuals no longer locked into the R.A.S.H. rationality from those still somewhat playing the R.A.S.H. game (i.e., 'disengaged' for now but still primarily reasoning within the R.A.S.H. logic).

The R.A.S.H. rationality should not be conceptualized as the manifestation of some mental disorder (as many scholars have correctly noted previously). It might be better to view it as flowing from the elicitations of cognitive mechanisms that evolved in a zerosumness-saturated world. The R.A.S.H. proposal weaves together the principal components we see playing a role in radicalization: envy and the deflection of responsibility, persuasion and diffusion of responsibility, and the alignment of interests for efficiency. This might explain why small groups of male friends are over-represented among jihadists. ${ }^{192}$ Also, if our model offers some validity, in agreement with Lankford, ${ }^{193}$ the insistence on maintaining a distinction between loners and those radicalized individuals belonging to collectives should be discarded. We see little difference in the process but for the fact that loners would be individuals who have not found a collective. In essence, the actions of those lacking such an active affiliation may very well still belong to the R.A.S.H. logic of the action behavioral choice.

It should come as no surprise that radicalized extremists typically emerge from divided ethnic or religious sociopolitical milieus. ${ }^{194}$ Such environments provide the necessary, but not sufficient, conditions for envy to thrive. Social environments characterized by constraints, scarcity, and inter-coalitional cleavages are more likely to evoke zero-sum thinking and the associated envy which seeks to level the playing field 
when significant differences are detected. In such a socioscape, internal competition for welfare-enhancing alliance building which allow access to social resources is a prominent feature. A meta-analysis of radicalization risk factors found that a low degree of integration within the wider society combined with a strong identification with a minority identity had a significant effect on the likelihood of holding radicalized attitudes and having engaged in violent actions. ${ }^{195}$ In a sample of European neo-jihadi terrorists, Bakker ${ }^{196}$ found that the families of approximately $92 \%$ of those were of extra-European origin (i.e., the neo-jihadists were first, second, or third generation migrants). Radicalized extremists often typically emerge from divided ethnic or religious sociopolitical milieus. 197 Such logic may also account for why Jacobson \& Deckard ${ }^{198}$ found that social characteristics typical of fractionalized tribal systems - hostility toward central thirdparty institutions, nested grievances and feuding, and corruption - are particularly conducive to the emergence of violent extremism.

We should not ignore the role that incentives play in the rationality underlying the R.A.S.H. model which entails the maximization of one's utility. Indeed, that incentives matter is illustrated by the impact on the behavior of terrorists perceiving the dramatic increase in risk under state pressure 199 or the shift in public opinion making obvious the lowering of popular support. ${ }^{200}$ As noted by Ashour ${ }^{201}$ "[State] repression forced the IG leadership to reassess the costs and the benefits of violently confronting the Egyptian regime. They have found that the costs of the confrontation outweigh the benefits and, therefore, they came to the conclusion that jihad is Islamically forbidden in this case." Scholars have also noted how young militants are generally highly regarded by ingroup non-combatants. ${ }^{202}$ The perception of support coming from the wider population alter the cost/benefit analysis of radicalized action. ${ }^{203}$ The ability to gain status, prestige, and other social rewards among peers and/or the wider population is regularly cited as a motivation for militants of all types, ${ }^{204}$ while the reduction of the potential benefits to be obtained has strong effects on disengagement and deradicalization. ${ }^{205}$

The hypotheses that have been proposed in this model will need to be investigated indepth, both ethnographically and experimentally. However, if accurate, the model challenges assumptions of existing programs aimed at combating radicalization that are currently part of State efforts for 'preventing' or 'countering' violent extremism (P/CVE). Many areas of activity of $\mathrm{P} / \mathrm{CVE}$ programs, such as, for instance, costly programs targeting ideological change or educating youth about the dangers of violent extremism, are likely to be unsuccessful at reducing violent extremism. Efforts which would help to mitigate coalitional cleavages and promote an assimilationist agenda ${ }^{206}$ would most probably be more successful. Also, addressing the 'elephant in the room' - that self-interest and envy are core components of the process of radicalization - would help. In line with our model, a deradicalization intervention provider in the United Kingdom notes how his method involves "[persuading] clients to take responsibility for their views or prejudices rather than blaming external factors" and "questioning why the Koran is being used as justification for domestic violence or the formation of a caliphate". ${ }^{207}$ Finally, deterrence should also be a core part of the solution. ${ }^{208}$ It should involve the clear publicity of the risks involved and the limits of acceptable behaviors beyond which someone excludes oneself from expansive moral considerations. 


\section{ACKNOWLEDGEMENTS}

The authors would like to thank Pascal Boyer, Katelyn DiBenedetto, Matthew Martinez, Ilya Sobol, and Daniel Sznycer for their feedback on previous drafts.

\section{DISCLOSURE STATEMENT}

No potential competing interest was reported by the authors.

\section{BIOGRAPHICAL NOTE}

Michael Moncrieff is a postdoctoral researcher in social science at the Law Faculty of the University of Geneva, Department of International Public Law and International Organization. He specializes in the sociopolitical and psychological causes of radicalization and the effectiveness of policies to prevent and combat violent extremism. Michael is part of the project 'Preventing and Combating Terrorism and Violent Extremism: Towards a Legal-Empirical Approach’. Email: michael.moncrieff@unige.ch

Pierre Lienard is a professor in Sociocultural Anthropology at The University of Nevada, Las Vegas, USA. His research on informal institutions and social coordination blends the theoretical import of various disciplines such as anthropology, evolutionary and cognitive psychologies, behavioral ecology, and institutional studies. Email: pierre.lienard@unlv.edu

\section{ORCID}

Michael Moncrieff: https://orcid.org/o0o0-0001-5190-7823 


\section{NOTES}

1 "The Stagnation in Terrorism Research," Terrorism and Political Violence 26, no. 4 (September 2014): 565-80, https://doi.org/10.1080/09546553.2014.895649.

2 Whereas Sageman focuses primarily on methodological concerns, we focus on theoretical issues.

3 The concept of emotion will be used with different acceptations: first, as descriptor of an affective experience (section 3.2); second, as label for the computational logic moving the individual to radicalize (section 3.5), and third, as intuitive templates manipulated as argumentative operators (sections 4.4 \& 4.5). 4 "The Evolutionary Psychology of the Emotions and Their Relationship to Internal Regulatory Variables," in Handbook of Emotions, 3rd Ed (New York, NY, US: The Guilford Press, 2008), 117.

5 See also: Laith Al-Shawaf et al., "Human Emotions: An Evolutionary Psychological Perspective," Emotion Review 8, no. 2 (April 1, 2016): 173-86, https://doi.org/10.1177/1754073914565518; Debra Lieberman and Carlton Patrick, Objection: Disgust, Morality, and the Law (Oxford University Press, 2018), 36.

6 Tooby and Cosmides, "The Evolutionary Psychology of the Emotions and Their Relationship to Internal Regulatory Variables," 118.

7 Tooby and Cosmides, 118.

8 Tooby and Cosmides, 123 .

9 Sznycer has advanced the hypothesis of the existence of a psychology for social antagonism which predicts that in a situation where the agent conceives of his interactions with some others as competitive (zero-sum), his social standing determines the core emotion that will drive his attitude and behavior (D. Sznycer, personal communication, May 21, 2021). As Fiske has proposed, one would envy up and scorn down (Susan T. Fiske, Envy up, Scorn down: How Status Divides Us (Russell Sage Foundation, 2011).. The process of radicalization, we propose, involves individuals in situations of lower standing, actual, assumed, or presumed.

${ }^{10}$ Joel A. Capellan, "Lone Wolf Terrorist or Deranged Shooter? A Study of Ideological Active Shooter Events in the United States, 1970-2014," Studies in Conflict \& Terrorism 38, no. 6 (2015): 395-413; Kathleen Deloughery, Ryan D. King, and Victor Asal, "Close Cousins or Distant Relatives? The Relationship between Terrorism and Hate Crime," Crime \& Delinquency 58, no. 5 (2012): 663-88; Adam Lankford, "Identifying Potential Mass Shooters and Suicide Terrorists With Warning Signs of Suicide, Perceived Victimization, and Desires for Attention or Fame," Journal of Personality Assessment 100, no. 5 (September 3, 2018): 471-82, https://doi.org/10.1080/00223891.2018.1436063; Clark McCauley, Sophia Moskalenko, and Benjamin Van Son, "Characteristics of Lone-Wolf Violent Offenders: A Comparison of Assassins and School Attackers," Perspectives on Terrorism 7, no. 1 (2013): 4-24.

${ }_{11}$ This is not to say that the study of statements offered by militants would be entirely futile. However, we must remember that when we are asked to make sense of our actions, our answers will inevitably have the tenor of a justification, hence those answers should be biased in strategic ways given the specific demands of the interaction (see Mercier and Sperber, 2017). Being asked to convey the gist of one's experience might put less of an emphasis on the provision of acceptable reasons, even if some aspects of that experience will be downplayed to match expected standards of decency and respectability. Note also that, even if a statement is a post-hoc justification of an action and appears so, thanks to a careful linguistic analysis, for instance, it might still provide clues for the original motivations.

12 Donald Davidson, Essays on Actions and Events: Philosophical Essays Volume 1, vol. 1 (Oxford University Press, 2001), 8.

13 Davidson, 1:3-4.

14 The Enigma of Reason (Harvard University Press, 2017).

15 Mercier and Sperber, 8.

16 The Enigma of Reason.

17 Bibi van Ginkel et al., "The Foreign Fighters Phenomenon in the European Union. Profiles, Threats \& Policies" (The Hague: International Institute for Counter-Terrorism, April 1, 2016), http://icct.nl/publication/report-the-foreign-fighters-phenomenon-in-the-eu-profiles-threats-policies/.

${ }^{18}$ In our example, true safety. In other cases, that safety is likely relative.

19 Gambetta and Hertog Engineers of Jihad: The Curious Connection between Violent Extremism and Education (Princeton, New Jersey: Princeton University Press, 2016). acknowledge that puzzle in their Engineers of Jihad: The Curious Connection between Violent Extremism and Education. A middle-class 
background or a relatively decent standard of living seem to more strongly qualify the background of many violent extremists.

20 "Radicalization: What Does It Mean," Home-Grown Terrorism, 2009, 101-13.

${ }^{21}$ E.g., Clark McCauley and Sophia Moskalenko, "Understanding Political Radicalization: The TwoPyramids Model.," American Psychologist 72, no. 3 (April 2017): 205-16, https://doi.org/10.1037/ampooooo62; Peter R. Neumann, "The Trouble with Radicalization," International Affairs 89, no. 4 (July 2013): 873-93, https://doi.org/10.1111/1468-2346.12049.

${ }^{22}$ See Rik Coolsaet, "Radicalization: The Origins and Limits of a Contested Concept," in Radicalisation in Belgium and the Netherlands: Critical Perspectives on Violence and Security (IB Tauris, 2019), 29-51.

23 Oluf Gøtzsche-Astrup, "The Time for Causal Designs: Review and Evaluation of Empirical Support for Mechanisms of Political Radicalisation," Aggression and Violent Behavior 39 (March 2018): 90-99, https://doi.org/10.1016/j.avb.2018.02.003.

24 E.g., Randy Borum, "Radicalization into Violent Extremism I: A Review of Social Science Theories," Journal of Strategic Security 4, no. 4 (December 2011): 7-36, https://doi.org/10.5038/1944-0472.4.4.1.; Neumann, "The Trouble with Radicalization."

25 Neumann, "The Trouble with Radicalization"; Sageman Turning to Political Violence: The Emergence of Terrorism (University of Pennsylvania Press, 2017); e.g., Jamie Bartlett and Carl Miller, "The Edge of Violence: Towards Telling the Difference Between Violent and Non-Violent Radicalization," Terrorism and Political Violence 24, no. 1 (January 2012): 1-21, https://doi.org/10.1080/o9546553.2011.594923; Borum, "Radicalization into Violent Extremism I"; Clark McCauley and Sophia Moskalenko, "Toward a Profile of Lone Wolf Terrorists: What Moves an Individual From Radical Opinion to Radical A," Terrorism and Political Violence 26, no. 1 (2014): 69-85.

26 "Radicalization: The Origins and Limits of a Contested Concept."

27 E.g., Marc Sageman, Turning to Political Violence: The Emergence of Terrorism (University of Pennsylvania Press, 2017).

28 This is not a moral argument, but a point about the instrumental contribution of such act to an advocated political goal. Think, for instance, of the individual intent on engaging in a knifing rampage knowing fullwell that he will be quickly shot dead.

${ }^{29}$ Although, the reasons provided must be just that, believable and convincing propositions, strong enough that they might indeed reasonably account for the increased risk the individual seems willing to take on.

30 "By-Product Mutualism and the Ambiguous Effects of Harsher Environments - A Game-Theoretic Model," Journal of Theoretical Biology 393 (March 2016): 82-97, https://doi.org/10.1016/j.jtbi.2015.12.034.

31 "Harsh Environments: Multi-Player Cooperation with Excludability and Congestion," Journal of Theoretical Biology 460 (January 2019): 18-36, https://doi.org/10.1016/j.jtbi.2018.10.006. Note again that we do not model situations of dynamic coordination; instead we model the mentality of the radicalized individual and the rationality that he brings to the task: the agent acts $a s$ if sticking to a set of preferences rank-ordering his behavioral options. For a similar approach, see Halevy, Nir, Eileen Y. Chou, and J. Keith Murnighan. "Mind games: The mental representation of conflict." Journal of personality and social psychology 102, no. 1 (2012): 132.

${ }^{2}$ De Jaegher and Hoyer, "By-Product Mutualism and the Ambiguous Effects of Harsher Environments A Game-Theoretic Model," 84.

33 De Jaegher and Hoyer, 84.

34 De Jaegher, "Harsh Environments."

35 Ahmed Ajil, "Leaving Peace for War: An Exploratory Study of Swiss Men's Trajectories toward Engagement in Arab Conflicts," PDF, 2019, https://doi.org/10.18753/2297-8224-138; Bartlett and Miller, "The Edge of Violence"; Kevin D. Haggerty and Sandra M. Bucerius, "Radicalization as Martialization: Towards a Better Appreciation for the Progression to Violence," Terrorism and Political Violence, January 8, 2018, 1-21, https://doi.org/10.1080/09546553.2017.1404455; Jessica Eve Stern, "X: A Case Study of a Swedish Neo-Nazi and His Reintegration into Swedish Society: X: A Case Study of a Swedish Neo-Nazi," Behavioral Sciences \& the Law 32, no. 3 (May 2014): 440-53, https://doi.org/10.1002/bsl.2119; Michael Wolfowicz et al., "A Field-Wide Systematic Review and Meta-Analysis of Putative Risk and Protective Factors for Radicalization Outcomes," Journal of Quantitative Criminology, December 3, 2019, https://doi.org/10.1007/s10940-019-09439-4.

${ }^{6} 6$ Ajil, "Leaving Peace for War."

37 Philip Baugut and Katharina Neumann, "Online News Media and Propaganda Influence on Radicalized Individuals: Findings from Interviews with Islamist Prisoners and Former Islamists," New Media \& 
Society, October 10, 2019, 1-25, https://doi.org/10.1177/1461444819879423; Simon Cottee and Keith Hayward, "Terrorist (E)Motives: The Existential Attractions of Terrorism," Studies in Conflict \& Terrorism 34, no. 12 (December 2011): 963-86, https://doi.org/10.1080/1057610X.2011.621116; Haggerty and Bucerius, "Radicalization as Martialization"; Gaetano Joe Ilardi, "Interviews With Canadian Radicals," Studies in Conflict \& Terrorism 36, no. 9 (September 2013): 713-38, https://doi.org/10.1080/1057610X.2013.813248; James Khalil, John Horgan, and Martine Zeuthen, "The Attitudes-Behaviors Corrective (ABC) Model of Violent Extremism," Terrorism and Political Violence, December 18, 2019, 1-26, https://doi.org/10.1080/o9546553.2019.1699793; John Meadowcroft and Elizabeth A Morrow, "Violence, Self-Worth, Solidarity and Stigma: How a Dissident, Far-Right Group Solves the Collective Action Problem," Political Studies 65, no. 2 (June 2017): 373-90, https://doi.org/10.1177/0032321716651654; Jerrold Post, Ehud Sprinzak, and Laurita Denny, "The Terrorists in Their Own Words: Interviews with 35 Incarcerated Middle Eastern Terrorists**This Research Was Conducted with the Support of the Smith Richardson Foundation.," Terrorism and Political Violence 15, no. 1 (March 2003): 171-84, https://doi.org/10.1080/09546550312331293007.

${ }_{38}^{8}$ Ajil, "Leaving Peace for War"; Baugut and Neumann, "Online News Media and Propaganda Influence on Radicalized Individuals."

39 Mirra Noor Milla, Faturochman, and Djamaludin Ancok, "The Impact of Leader-Follower Interactions on the Radicalization of Terrorists: A Case Study of the Bali Bombers: The Impact of Leader Follower Interactions on the Radicalization of Terrorists," Asian Journal of Social Psychology 16, no. 2 (June 2013): 92-100, https://doi.org/10.1111/ajsp.12007; Michaela Pfundmair et al., "Pathways toward Jihadism in Western Europe: An Empirical Exploration of a Comprehensive Model of Terrorist Radicalization," Terrorism and Political Violence, September 19, 2019, 1-23, https://doi.org/10.1080/09546553.2019.1663828; Pete Simi and Robert Futrell, "Negotiating White Power Activist Stigma," Social Problems 56, no. 1 (February 2009): 93, https://doi.org/10.1525/sp.2009.56.1.89.

40 Adam Lankford, "The Myth of Martyrdom: What Really Drives Suicide Bombers, Rampage Shooters, and Other Self-Destructive Killers," Behavioral and Brain Sciences 37, no. 4 (August 2014): 351-62, https://doi.org/10.1017/So140525X13001581; Marc Sageman, Leaderless Jihad Terror Networks in the Twenty-First Century (Philadelphia, PA: University of Pennsylvania Press, 2008).

41 "When Hate Speech Leads to Hateful Actions: A Corpus and Discourse Analytic Approach to Linguistic Threat Assessment of Hate Speech" (Dissertation, Washington DC, Georgetown University, 2019).

42 Marsters, 73.

43 Marsters, 73.

44 "Cognitive Mechanisms in Violent Extremism," Cognition 188 (July 2019): 116-23, https://doi.org/10.1016/j.cognition.2018.11.008.

45 Gerard Saucier et al., "Patterns of Thinking in Militant Extremism," Perspectives on Psychological Science 4, no. 3 (May 1, 2009): 256-71, https://doi.org/10.1111/j.1745-6924.2009.01123.x.

46 Sarah Knight, Katie Woodward, and Gary L. J. Lancaster, "Violent versus Nonviolent Actors: An Empirical Study of Different Types of Extremism.," Journal of Threat Assessment and Management 4, no. 4 (December 2017): 239-40, https://doi.org/10.1037/tamooooo86.

47 Ajil, "Leaving Peace for War"; Bartlett and Miller, "The Edge of Violence"; Ilardi, "Interviews With Canadian Radicals"; Stijn Sieckelinck and Micha de Winter, "Formers and Families: Transitional Journeys in and out of Extremisms in the United Kingdom, Denmark and The Netherlands" (The Hague: Nationaal Coördinator Terrorismebestrijding en Veiligheid, 2015).

48 That public face systematically frames the situation confronted, the risks incurred, the gains to be had and the potential ways of achieving some efficient resolution in terms of interdependencies (i.e., the 'we,' and the 'us' against 'them'). However, we propose that it is a later elaboration which says rather little about the actual prime mover of radicalization. We develop that part of our argument shortly.

49 More on that point when we discuss Mercier and Sperber's model of the interaction between intuitions and reasons.

$5^{\circ}$ More on that shortly when we present our full model of the prime-mover emotion.

${ }^{51}$ It certainly does not mean that among the radicalized militants we would not have cynical individuals, in the common understanding of being manipulators, selfish and hypocritical. There are many, without any doubt. Just that it is not our concern here. How much refined awareness of the process that leads to the production of such typical utterances an individual has will be case specific. 
$5^{2}$ E.g., Liran Goldman and Michael A. Hogg, "Going to Extremes for One's Group: The Role of Prototypicality and Group Acceptance," Journal of Applied Social Psychology 46, no. 9 (2016): 544-53, https://doi.org/10.1111/jasp.12382; Michael A. Hogg, "From Uncertainty to Extremism: Social Categorization and Identity Processes," Current Directions in Psychological Science 23, no. 5 (October 1, 2014): 338-42, https://doi.org/10.1177/0963721414540168; Michael A. Hogg and Janice Adelman, "Uncertainty-Identity Theory: Extreme Groups, Radical Behavior, and Authoritarian Leadership," Journal of Social Issues 69, no. 3 (2013): 436-54, https://doi.org/10.1111/josi.12023.

53 Henri Tajfel, "Experiments in Intergroup Discrimination," Scientific American 223, no. 5 (1970): 96103; Henri Tajfel, "La Catégorisation Sociale.," in Introduction à La Psychologie Sociale, vol. 1 (Paris: Larousse, 1972), 272-302; Henri Tajfel, Differentiation between Social Groups: Studies in the Social Psychology of Intergroup Relations. (Academic Press, 1978); Henri Tajfel, Human Groups and Social Categories: Studies in Social Psychology (Cup Archive, 1981); Henri Tajfel et al., "Social Categorization and Intergroup Behaviour," European Journal of Social Psychology 1, no. 2 (1971): 149-78; Henri Tajfel and John C. Turner, "An Integrative Theory of Intergroup Conflict," in Organizational Identity: A Reader, ed. William G. Austin and Stephen Worchel, vol. 56 (Oxford University Press Oxford, UK, 1979), 65; Henri Tajfel and J. C. Turner, "The Social Identity Theory of Inter-Group Behavior," Chigago: Nelson-Hall, 1986; John C. Turner, "Social Comparison and Social Identity: Some Prospects for Intergroup Behaviour," European Journal of Social Psychology 5, no. 1 (1975): 1-34; John C. Turner et al., Rediscovering the Social Group: A Self-Categorization Theory. (Basil Blackwell, 1987); for a succinct presentation of SIT, see Yzerbit and Demoulin, "Intergroup Relations," in Handbook of Social Psychology, ed. Susan T. Fiske, Daniel T. Gilbert, and Lindzey Gardner, 5th ed., vol. 2 (Hoboken, NJ, USA: Wiley, 2010), 1024-83.

54 Tajfel, "La Catégorisation Sociale."; Yzerbit and Demoulin, "Intergroup Relations," 1029.

55 Tajfel, "La Catégorisation Sociale."; Tajfel, Differentiation between Social Groups: Studies in the Social Psychology of Intergroup Relations.; Yzerbit and Demoulin, "Intergroup Relations," 1029.

${ }_{56}$ Tajfel, Differentiation between Social Groups: Studies in the Social Psychology of Intergroup Relations. 57 Tajfel and Turner, "An Integrative Theory of Intergroup Conflict"; Yzerbit and Demoulin, "Intergroup Relations," 1030.

$5^{8}$ Tajfel and Turner, "The Social Identity Theory of Inter-Group Behavior."

59 Tajfel and Turner.

60 Tajfel and Turner, "An Integrative Theory of Intergroup Conflict."

${ }^{61}$ E.g., Goldman and Hogg, "Going to Extremes for One's Group"; Hogg, "From Uncertainty to Extremism"; Hogg and Adelman, "Uncertainty-Identity Theory."

62 Hogg, "From Uncertainty to Extremism."

63 Goldman and Hogg, "Going to Extremes for One's Group."

64 "Evolution and Culture," Evolution and Social Psychology, 2006, 253.

65 Pascal Boyer, Rengin Firat, and Florian van Leeuwen, "Safety, Threat, and Stress in Intergroup Relations: A Coalitional Index Model," Perspectives on Psychological Science 10, no. 4 (July 2015): 434-50, https://doi.org/10.1177/1745691615583133.

66 For a more elegant way see Robert Kurzban, Why Everyone (Else) Is a Hypocrite: Evolution and the Modular Mind (Princeton University Press, 2012), 137. This is not to discard the importance of selfevaluation and the feeling that it might generate in terms of self-regard. Sedikides et al. propose different types of motives that would rely on self-evaluation, among which the valuation motives, focused on selfprotection and self-enhancement and the learning motives, about self-assessment and self-improvement. Feeling bad about oneself, i.e., experiencing a lowering of self-regard/esteem, could be the output of complex, partially implicit, computations alarming the agent to assess further one's involvement in the world and to consider some of the better choices and decisions that might have been or could still be made. Still, we do not think that self-evaluation and self-esteem are exactly reaching the level of prime movers involved in the process of radicalization. Sedikides, Constantine, John J. Skowronski, and Robin IM Dunbar. "When and why did the human self evolve." Evolution and social psychology (2006): 55-80.

${ }_{67}$ The True Believer: Thoughts on the Nature of Mass Movements, 1st Perennial classics ed, Perennial Classics (New York: Harper \& Brothers, 1951), 59.

${ }^{68}$ Hoffer, 59.

69 Hoffer, 68 ff.

$7^{70}$ See, for instance, Carsten K. W. De Dreu and Jörg Gross, "Revisiting the Form and Function of Conflict: Neurobiological, Psychological, and Cultural Mechanisms for Attack and Defense within and between Groups," Behavioral and Brain Sciences 42 (2019), https://doi.org/10.1017/So140525X18002170. 
${ }^{71}$ And it still is, which explains how generally bad we are at understanding the non-zero-sumness and efficiency of modern market exchanges. See Boyer, Pascal, and Michael Bang Petersen. "Folk-economic beliefs: An evolutionary cognitive model." Behavioral and Brain Sciences 41 (2018).

72 Robert Wright, Nonzero: The Logic of Human Destiny (Vintage, 2001).

73 See original idea in Helmut Schoeck, Envy: A Theory of Social Behaviour (Secker \& Warburg, 1966), 25.

74 For a treatment of that specific question, see Schoeck, Envy: A Theory of Social Behaviour.

7512.

${ }^{76}$ Schoeck, 24-25.

77 Aaron N Sell and Anthony C. Lopez, "Emotional Underpinnings of War: An Evolutionary Analysis of Anger and Hatred," in The International Handbook on Collective Violence: Current Issues and Perspectives, ed. Carol A. Ireland et al. (Routledge, 2020), 34; Tooby and Cosmides, "The Evolutionary Psychology of the Emotions and Their Relationship to Internal Regulatory Variables."

78 George M. Foster et al., "The Anatomy of Envy: A Study in Symbolic Behavior [and Comments and Reply]," Current Anthropology 13, no. 2 (1972): 165-202; W. Gerrod Parrott and Patricia M. Rodriguez Mosquera, "On the Pleasures and Displeasures of Being Envied.," 2008; Patricia M. Rodriguez Mosquera, W. Gerrod Parrott, and Alejandra Hurtado de Mendoza, "I Fear Your Envy, I Rejoice in Your Coveting: On the Ambivalent Experience of Being Envied by Others.," Journal of Personality and Social Psychology 99, no. 5 (2010): 842; Niels Van de Ven, Marcel Zeelenberg, and Rik Pieters, "Warding off the Evil Eye: When the Fear of Being Envied Increases Prosocial Behavior," Psychological Science 21, no. 11 (2010): 1671-77. 79 Envy: A Theory of Social Behaviour, 5-6.

80 This claim should be understood within the framework of a zero-sum world, as the case was made above. ${ }^{81}$ Schoeck, Envy: A Theory of Social Behaviour, 11.

82 The Rousseauist myth of the noble savage is hard to extinguish indeed.

83 For the original treatment that inspired the model proposed above, see Schoeck, Envy: A Theory of Social Behaviour, 33ff. Given envy's destructive impulse, most economists would view envy as inefficient. In our modern economic world where many zero-sum interactions have been all but eliminated, it is indeed correct. In the ancestral environment in which the emotion evolved, an environment with very little growth, it must have been quite functional for an agent to be endowed with such disposition. More generally, that emotion might have had the effect of containing what could have been very costly inequalities that would not have maximized the success of one's community.

84 In a zero-sum perspective, another individual's success hurts (P. Boyer, personal communication, May 17, 2021). In fact, it literally does so. Indeed, envy activates the dorsal AAC where social pain is processed Hidehiko Takahashi et al., "When Your Gain Is My Pain and Your Pain Is My Gain: Neural Correlates of Envy and Schadenfreude," Science 323, no. 5916 (2009): 937-39..

85 That combination of grievance and unearned advantage (i.e., involving some form of foul play) might also be at the source of conspiracy theories. It might explain why once the postulated intolerable situation the individual faces has found its collective expression, such productions typically emerge.

86 In order to be efficient in our Paleolithic zero-sum world, we would expect the trigger-happiness of such a disposition. Vigilance should be constant and motivation to address early perceived differentials, given the agent's privileged knowledge of his/her own performance, status and abilities, powerful.

${ }^{87}$ Schoeck, Envy: A Theory of Social Behaviour, 25.

88 Why Kids Kill: Inside the Minds of School Shooters (Macmillan, 2009), 150.

89 Langman, 98.

90 Langman, 150.

${ }^{91}$ Langman, 53, emphasis in the original.

92 Langman, 150.

93150.

94 E.g., James L. Knoll IV and J. Reid Meloy, "Mass Murder and the Violent Paranoid Spectrum," Psychiatric Annals 44, no. 5 (2014): 236-43; J. Reid Meloy et al., "A Comparative Analysis of North American Adolescent and Adult Mass Murderers," Behavioral Sciences \& the Law 22, no. 3 (2004): 291309, https://doi.org/10.1002/bsl.586; Chrystie Myketiak, "Fragile Masculinity: Social Inequalities in the Narrative Frame and Discursive Construction of a Mass Shooter's Autobiography/Manifesto," Contemporary Social Science 11, no. 4 (October 2016): 289-303, https://doi.org/10.1080/21582041.2016.1213414.

95 Lewis R. Gale, Will Carrington Heath, and Rand W. Ressler, "An Economic Analysis of Hate Crime," Eastern Economic Journal 28, no. 2 (2002): 203-16.

${ }^{96}$ Gale, Heath, and Ressler. 
97 Larry Ray, David Smith, and Liz Wastell, "Shame, Rage and Racist Violence," British Journal of Criminology 44, no. 3 (2004): 363.

$9^{8}$ Envy up, Scorn down: How Status Divides Us, 130.

99 E.g., Daniel Pipes, "Dealing with Middle Eastern Conspiracy Theories," Orbis 36 (1992): 41-56; Arne Johan Vetlesen, "The Immorality of Terrorism and the Ethical Core of the Envy That Spurs It," Irish Journal of Sociology 15, no. 1 (2006): 67-80; Simona Trip et al., "Psychological Mechanisms Involved in Radicalization and Extremism. A Rational Emotive Behavioral Conceptualization," Frontiers in Psychology 10 (March 6, 2019), https://doi.org/10.3389/fpsyg.2019.00437.

100 "Incel (E)Motives: Resentment, Shame and Revenge," Studies in Conflict \& Terrorism 44, no. 2 (February 1, 2021): 93-114, https://doi.org/10.1080/1057610X.2020.1822589.

${ }^{101}$ Bruce Hoffman, Jacob Ware, and Ezra Shapiro, "Assessing the Threat of Incel Violence," Studies in Conflict \& Terrorism 43, no. 7 (July 2, 2020): 565-87, https://doi.org/10.1080/1057610X.2020.1751459.

102 December Maxwell et al., "A Short Story of a Lonely Guy': A Qualitative Thematic Analysis of Involuntary Celibacy Using Reddit," Sexuality \& Culture 24, no. 6 (December 2020): 1862, https://doi.org/10.1007/s12119-020-09724-6. For another insightful example, see Myketiak, "Fragile Masculinity," 296-97.

103 E.g., Cottee, "Incel (E)Motives"; Hoffman, Ware, and Shapiro, "Assessing the Threat of Incel Violence"; Mark Juergensmeyer, Terror in the Mind of God: The Global Rise of Religious Violence, vol. 13 (Univ of California Press, 2017), 241.

104 Its evocation only requires the perception of a disadvantage.

105 I.e., the 'unjustifiability' of the behavior occupies the initiatory position for any further downstream computation. Thus, odds are strongly stacked against such an attitude.

106 David Pietraszewski, "How the Mind Sees Coalitional and Group Conflict: The Evolutionary Invariances of n-Person Conflict Dynamics," Evolution and Human Behavior 37, no. 6 (November 2016): 475, https://doi.org/10.1016/j.evolhumbehav.2016.04.006.

107 E.g., Pat Barclay, "Strategies for Cooperation in Biological Markets, Especially for Humans," Evolution and Human Behavior 34, no. 3 (2013): 164-75. Note too that destructive envy-driven actions directed at superior in-group members reduces the group's overall welfare as it harms, at a minimum, the welfare of both the envier and the envied without benefiting the standing of the group whatsoever. See, Robert $\mathrm{H}$. Frank, Choosing the Right Pond: Human Behavior and the Quest for Status. (Oxford University Press, 1985); Sarah E. Hill and David M. Buss, "The Evolutionary Psychology of Envy.," 2008; Inga Wobker and Peter Kenning, "Drivers and Outcome of Destructive Envy Behavior in an Economic Game Setting," Schmalenbach Business Review 65, no. 2 (2013): 173-94.

108 Robert H. Frank, Passions within Reason: The Strategic Role of the Emotions. (WW Norton \& Co, 1988); Robert H. Frank, What Price the Moral High Ground?: Ethical Dilemmas in Competitive Environments (Princeton University Press Princeton, NJ, 2004).

109 Foster et al., "The Anatomy of Envy: A Study in Symbolic Behavior [and Comments and Reply]"; Parrott and Rodriguez Mosquera, "On the Pleasures and Displeasures of Being Envied."; Rodriguez Mosquera, Parrott, and Hurtado de Mendoza, "I Fear Your Envy, I Rejoice in Your Coveting: On the Ambivalent Experience of Being Envied by Others."; Van de Ven, Zeelenberg, and Pieters, "Warding off the Evil Eye: When the Fear of Being Envied Increases Prosocial Behavior."

110 Nicolas Baumard, Jean-Baptiste André, and Dan Sperber, "A Mutualistic Approach to Morality: The Evolution of Fairness by Partner Choice," Behavioral and Brain Sciences 36, no. 01 (February 1, 2013): 5978, https://doi.org/10.1017/So140525X11002202.

111 "The Perception of Envy," Social Psychology 41, no. 2 (1978): 105-17, https://doi.org/10.2307/3033570. 112 That is, the individual should become increasingly less the focus of positive social interactions (as in situations when cooperation, support and succor are offered), but more so, the destination of negative investments (as in situations when harm is inflicted, for instance). See Daniel Sznycer et al., "Shame Closely Tracks the Threat of Devaluation by Others, Even across Cultures," Proceedings of the National Academy of Sciences 113, no. 10 (March 8, 2016): 2625-30, https://doi.org/10.1073/pnas.1514699113.

113 Sznycer et al.

114 Richard H. Smith, "Envy and Its Transmutations," The Social Life of Emotions, 2004, 43-63.

115 Maria Miceli and Cristiano Castelfranchi, "The Envious Mind," Cognition \& Emotion 21, no. 3 (April 2007): 449-79, https://doi.org/10.1080/02699930600814735; Richard H. Smith and Sung Hee Kim, "Comprehending Envy.," Psychological Bulletin 133, no. 1 (2007): 46.

${ }_{116}$ "Episodic Envy," Journal of Applied Social Psychology 39, no. 9 (2009): 2128-73, https://doi.org/10.1111/j.1559-1816.2009.00519.x. 
${ }_{117}$ De Dreu and Gross, "Revisiting the Form and Function of Conflict"; Anthony C. Lopez, "The Evolutionary Psychology of War: Offense and Defense in the Adapted Mind," Evolutionary Psychology 15, no. 4 (October 2017): 147470491774272, https://doi.org/10.1177/1474704917742720; Anthony C. Lopez, "Making 'My' Problem 'Our' Problem: Warfare as Collective Action, and the Role of Leader Manipulation," The Leadership Quarterly, May 2019, https://doi.org/10.1016/j.leaqua.2019.05.001; Pietraszewski, "How the Mind Sees Coalitional and Group Conflict."

${ }_{118}$ Daniel Sznycer et al., "Support for Redistribution Is Shaped by Compassion, Envy, and Self-Interest, but Not a Taste for Fairness," Proceedings of the National Academy of Sciences 114, no. 31 (August 1, 2017): 8420-25, https://doi.org/10.1073/pnas.1703801114.

119 De Dreu and Gross, "Revisiting the Form and Function of Conflict"; Lopez, "The Evolutionary Psychology of War"; Pietraszewski, "How the Mind Sees Coalitional and Group Conflict."

${ }^{120}$ William H. Durham, "Resource Competition and Human Aggression, Part I: A Review of Primitive War," The Quarterly Review of Biology 51, no. 3 (1976): 385-415; Lopez, "The Evolutionary Psychology of War"; Lopez, "Making 'My' Problem 'Our' Problem"; John Tooby and Leda Cosmides, "The Evolution of War and Its Cognitive Foundations" 8 (1988): 1-15.

${ }^{121}$ We simplify the matter, as deterrence would complexify the argument. Luke Glowacki and Richard Wrangham, "Warfare and Reproductive Success in a Tribal Population," Proceedings of the National Academy of Sciences 112, no. 2 (January 13, 2015): 348-53, https://doi.org/10.1073/pnas.1412287112; Luke Glowacki and Richard W. Wrangham, "The Role of Rewards in Motivating Participation in Simple Warfare," Human Nature 24, no. 4 (December 2013): 444-6o, https://doi.org/10.1007/s12110-013-91788.

${ }^{122}$ Lopez, "The Evolutionary Psychology of War."

123 De Dreu and Gross, "Revisiting the Form and Function of Conflict."

124 De Dreu and Gross.

125 E.g., Bartlett and Miller, “The Edge of Violence”; Cottee and Hayward, “Terrorist (E)Motives”; Haggerty and Bucerius, "Radicalization as Martialization"; Mark Jeurgensmeyer, Terror in the Mind of God (University of California Press, 2001); Elena Mastors and Rhea Siers, "Omar Al-Hammami: A Case Study in Radicalization," Behavioral Sciences \& the Law 32, no. 3 (2014): 377-88, https://doi.org/10.1002/bsl.2108; Birga M. Schumpe et al., "The Role of Sensation Seeking in Political Violence: An Extension of the Significance Quest Theory.," Journal of Personality and Social Psychology 118, no. 4 (2018): 743; Stern, "X."

126 Wolfowicz et al., "A Field-Wide Systematic Review and Meta-Analysis of Putative Risk and Protective Factors for Radicalization Outcomes."

127 Evolutionary models predict that males would benefit more than females from participating in offensive aggression, while there should not be any sex differences when it comes to defense Lopez, "The Evolutionary Psychology of War"; Melissa M. McDonald, Carlos David Navarrete, and Mark Van Vugt, "Evolution and the Psychology of Intergroup Conflict: The Male Warrior Hypothesis," Philosophical Transactions of the Royal Society B: Biological Sciences 367, no. 1589 (March 5, 2012): 670-79, https://doi.org/10.1098/rstb.2011.0301; Tooby and Cosmides, "The Evolution of War and Its Cognitive Foundations.”. This may partially explain why men are overwhelmingly more likely to get radicalized to the point of committing violent acts; one of the most consistent findings in the radicalization literature see "National Consortium for the Study of Terrorism and Responses to Terrorism (START)," Profiles of Individual Radicalization in the United States [Data file], 2018, http://www.start.umd.edu/pirus; Pfundmair et al., "Pathways toward Jihadism in Western Europe."

128 Ajil, "Leaving Peace for War," 17.

129 Albeit, see Fiske, Envy up, Scorn down: How Status Divides Us.

${ }_{130}$ The explanations of the phenomenon of radicalization in the literature thus mirror the claims typically being made by the perpetrators.

${ }^{131}$ Mia Bloom, "Dying to Kill: Motivations for Suicide Terrorism," in Root Causes of Suicide Terrorism (Routledge, 2006), 45-73; Sageman, Turning to Political Violence; Anne Speckhard, "The Lethal Cocktail of Terrorism: The Four Necessary Ingredients That Go into Making a Terrorist \& Fifty Individual Vulnerabilities/Motivations That May Also Play a Role" (International Center for the Study of Violent Extremism, 2016).

${ }_{132}$ Bloom, "Dying to Kill: Motivations for Suicide Terrorism"; Ilardi, "Interviews With Canadian Radicals"; Ariel Merari et al., "Making Palestinian 'Martyrdom Operations'/'Suicide Attacks': Interviews With WouldBe Perpetrators and Organizers," Terrorism and Political Violence 22, no. 1 (December 22, 2009): 102-19, https://doi.org/10.1080/09546550903409403; Ami Pedahzur, Suicide Terrorism (Polity, 2005). 
133 Ajil, "Leaving Peace for War"; Bartlett and Miller, "The Edge of Violence"; Cottee and Hayward, "Terrorist (E)Motives"; Ilardi, "Interviews With Canadian Radicals"; Enzo Nussio, "Emotional Legacies of War among Former Colombian Paramilitaries.," Peace and Conflict: Journal of Peace Psychology 18, no. 4 (2012): 369-83, https://doi.org/10.1037/aoo30327; Stern, "X."

134 Matthew Kriner, "Tackling Terrorism's Taboo: Shame," Perspectives on Terrorism 12, no. 2 (2018): 13; Clark McCauley, "Toward a Psychology of Humiliation in Asymmetric Conflict.," American Psychologist 72, no. 3 (April 2017): 255-65, https://doi.org/10.1037/ampooo0063; Speckhard, "The Lethal Cocktail of Terrorism: The Four Necessary Ingredients That Go into Making a Terrorist \& Fifty Individual Vulnerabilities/Motivations That May Also Play a Role"; Jessica Stern, "Terror in the Name of God" (Ecco New York, 2003); David Webber et al., "Divergent Paths to Martyrdom and Significance Among Suicide Attackers," Terrorism and Political Violence 29, no. 5 (September 3, 2017): 852-74, https://doi.org/10.1080/09546553.2015.1075979.

135 E.g., Ajil, "Leaving Peace for War"; Baugut and Neumann, "Online News Media and Propaganda Influence on Radicalized Individuals"; Bloom, “Dying to Kill: Motivations for Suicide Terrorism”; Donatella Della Porta, Clandestine Political Violence (Cambridge University Press, 2013); Mauricio Florez-Morris, "Joining Guerrilla Groups in Colombia: Individual Motivations and Processes for Entering a Violent Organization," Studies in Conflict \& Terrorism 30, no. 7 (June 4, 2007): 615-34, https://doi.org/10.1080/10576100701385958; John Horgan, The Psychology of Terrorism (Routledge, 2004); Clark R. McCauley and Sophia Moskalenko, Friction: How Radicalization Happens to Them and Us (Oxford ; New York: Oxford University Press, 2011); Pedahzur, Suicide Terrorism; Post, Sprinzak, and Denny, "The Terrorists in Their Own Words"; Marc Sageman, Understanding Terror Networks (Philadelphia: University of Pennsylvania Press, 2004); Sageman, Leaderless Jihad Terror Networks in the Twenty-First Century; Sageman, Turning to Political Violence; Stern, "Terror in the Name of God"; Webber et al., "Divergent Paths to Martyrdom and Significance Among Suicide Attackers."

${ }^{136}$ Randy Borum, "The Etiology of Radicalization," The Handbook of the Criminology of Terrorism, 2017, 218-19; Mohammed Hafez and Creighton Mullins, "The Radicalization Puzzle: A Theoretical Synthesis of Empirical Approaches to Homegrown Extremism," Studies in Conflict \& Terrorism 38, no. 11 (November 2, 2015): 958-75, https://doi.org/10.1080/1057610X.2015.1051375; Clark McCauley and Sophia Moskalenko, "Mechanisms of Political Radicalization: Pathways Toward Terrorism," Terrorism and Political Violence 20, no. 3 (July 2008): 415-33, https://doi.org/10.1080/09546550802073367; Fathali M. Moghaddam, "The Staircase to Terrorism: A Psychological Exploration.," American Psychologist 60, no. 2 (2005): 161-69, https://doi.org/10.1037/o003-066X.60.2.161; Mark Sedgwick, "The Concept of Radicalization as a Source of Confusion," Terrorism and Political Violence 22, no. 4 (September 14, 2010): 479-94, https://doi.org/10.1080/09546553.2010.491009.

137 E.g., Clark McCauley, "Jujitsu Politics: Terrorism and Response to Terrorism," in Collateral Damage: The Psychological Consequences of America's War on Terrorism, ed. Paul Kimmel and Chris Stout (Westport, CT: Praeger, 2006), 46; Sageman, Turning to Political Violence, 11.

138 "The Social Psychological Makings of a Terrorist," Current Opinion in Psychology 19 (February 2018): 131-34, https://doi.org/10.1016/j.copsyc.2017.03.024.

139 Webber and Arie W. Kruglanski.

140 Arie W. Kruglanski et al., "The Making of Violent Extremists," Review of General Psychology 22, no. 1 (March 1, 2018): 107-20, https://doi.org/10.1037/gproooo144; Arie W. Kruglanski, "Violent Radicalism and the Psychology of Prepossession," Social Psychological Bulletin 13, no. 4 (December 28, 2018), https://doi.org/10.32872/spb.v13i4.27449; Arie W. Kruglanski and Preben Bertelsen, "Life Psychology and Significance Quest: A Complementary Approach to Violent Extremism and Counter-Radicalisation," Journal of Policing, Intelligence and Counter Terrorism, February 23, 2020, 1-22, https://doi.org/10.1080/18335330.2020.1725098.

${ }^{141}$ Katarzyna Jasko, Gary LaFree, and Arie W. Kruglanski, "Quest for Significance and Violent Extremism: The Case of Domestic Radicalization: Quest for Significance and Violent Extremism," Political Psychology 38, no. 5 (October 2017): 815-31, https://doi.org/10.1111/pops.12376; Arie W. Kruglanski, Jocelyn J. Bélanger, and Rohan Gunaratna, The Three Pillars of Radicalization: Needs, Narratives, and Networks (Oxford University Press, USA, 2019); Arie W. Kruglanski et al., "Fully Committed: Suicide Bombers' Motivation and the Quest for Personal Significance: Significance Quest and Suicide Terrorism," Political Psychology 30, no. 3 (May 8, 2009): 331-57, https://doi.org/10.1111/j.1467-9221.2009.00698.x; Arie W. Kruglanski et al., "Terrorism-A (Self) Love Story: Redirecting the Significance Quest Can End Violence.," American Psychologist 68, no. 7 (2013): 559-75, https://doi.org/10.1037/a0032615; Arie W. Kruglanski et al., "The Psychology of Radicalization and Deradicalization: How Significance Quest Impacts Violent 
Extremism: Processes of Radicalization and Deradicalization,” Political Psychology 35 (February 2014): 69-93, https://doi.org/10.1111/pops.12163; Arie W. Kruglanski et al., "To the Fringe and Back: Violent Extremism and the Psychology of Deviance.," American Psychologist 72, no. 3 (April 2017): 217-30, https://doi.org/10.1037/ampooooo91; Kruglanski et al., "Cognitive Mechanisms in Violent Extremism"; Webber et al., "Divergent Paths to Martyrdom and Significance Among Suicide Attackers"; David Webber et al., "The Road to Extremism: Field and Experimental Evidence That Significance Loss-Induced Need for Closure Fosters Radicalization.," Journal of Personality and Social Psychology 114, no. 2 (February 2018): 270-85, https://doi.org/10.1037/pspioooo111.

${ }_{142}$ Kruglanski, Bélanger, and Gunaratna, The Three Pillars of Radicalization: Needs, Narratives, and Networks.

143 "The Social Psychological Makings of a Terrorist."

144 "Interviews With Canadian Radicals," 721.

145 Lieberman and Patrick, Objection: Disgust, Morality, and the Law, 37.

146 E.g., Daniel Sznycer, "Forms and Functions of the Self-Conscious Emotions," Trends in Cognitive Sciences 23, no. 2 (February 2019): 143-57, https://doi.org/10.1016/j.tics.2018.11.007; Sznycer et al., "Shame Closely Tracks the Threat of Devaluation by Others, Even across Cultures"; Daniel Sznycer and Aaron W. Lukaszewski, "The Emotion-Valuation Constellation: Multiple Emotions Are Governed by a Common Grammar of Social Valuation," Evolution and Human Behavior 40, no. 4 (July 2019): 395-404, https://doi.org/10.1016/j.evolhumbehav.2019.05.002; John Tooby et al., "Internal Regulatory Variables and the Design of Human Motivation: A Computational and Evolutionary Approach," in Handbook of Approach and Avoidance Motivation, ed. Andrew Elliot (New York, NY: Psychology Press, 2008).

147 John Tooby and Leda Cosmides, "Groups in Mind: The Coalitional Roots of War and Morality," in Human Morality and Sociality, ed. Henrik Hogh-Olesen, Christophe Boesch, and Leda Cosmides (London: Macmillan Education UK, 2010), 205, https://doi.org/10.1007/978-1-137-05001-4_8.

${ }_{148}$ Kruglanski et al., "The Psychology of Radicalization and Deradicalization"; McCauley, "Toward a Psychology of Humiliation in Asymmetric Conflict."; Webber and Arie W. Kruglanski, "The Social Psychological Makings of a Terrorist.”

149 "Humiliation: Causes, Correlates, and Consequences," in The Self-Conscious Emotions: Theory and Research (Guilford Press, 2007), 314.

${ }_{150}$ Elison and Harter, "Humiliation: Causes, Correlates, and Consequences."

${ }_{151}$ "Distinguishing Shame, Humiliation and Guilt: An Evolutionary Functional Analysis and Compassion Focused Interventions," in The Bright Side of Shame (Springer, 2019), 413-31.

152 "Humiliation and the Inertia Effect: Implications for Understanding Violence and Compromise in Intractable Intergroup Conflicts," Journal of Cognition and Culture 8, no. 3 (August 1, 2008): 281-94, https://doi.org/10.1163/156853708X358182.

153 "Micro-Mobilization into Armed Groups: Ideological, Instrumental and Solidaristic Paths," Qualitative Sociology 35, no. 4 (December 2012): 379, https://doi.org/10.1007/s11133-012-9237-1.

154 Ajil, "Leaving Peace for War," 13.

155 Ilardi, "Interviews With Canadian Radicals," 722.

${ }_{156}$ Zbigniew Małysz, "Towards a Redefinition of Islamic Sucide Terrorist's Motivation: An 'Altruistic' Terrorist Model," Polish Political Science Studies 67 (2020): 23; Rick O'Gorman and Andrew Silke, "Terrorism as Altruism: An Evolutionary Model for Understanding Terrorist Psychology," in Evolutionary Psychology and Terrorism, ed. Max Taylor, Jason Roach, and Ken Pease (London, UK: Routledge, 2015), 149-63; Robert Anthony Pape, Dying to Win: The Strategic Logic of Suicide Terrorism (Random House Incorporated, 2006), 184.

157 E.g., Goldman and Hogg, "Going to Extremes for One's Group”; Hogg, "From Uncertainty to Extremism”; Hogg and Adelman, "Uncertainty-Identity Theory."

${ }_{158}$ Sznycer et al., "Support for Redistribution Is Shaped by Compassion, Envy, and Self-Interest, but Not a Taste for Fairness."

159 Russell Hardin, One for All: The Logic of Group Conflict (Princeton, N.J: Princeton University Press, 1995); Tooby and Cosmides, "Groups in Mind: The Coalitional Roots of War and Morality."

160 "Impact of Perceived Peer Attitudes and Social Network Diversity on Violent Extremist Intentions," Terrorism and Political Violence, 2020, 1-19.

${ }^{161}$ Sageman, Turning to Political Violence, 6; Bart Schuurman et al., "End of the Lone Wolf: The Typology That Should Not Have Been," Studies in Conflict \& Terrorism 42, no. 8 (August 3, 2019): 771-78, https://doi.org/10.1080/1057610X.2017.1419554. 
162 E.g., Peter Langman, "Different Types of Role Model Influence and Fame Seeking Among Mass Killers and Copycat Offenders," American Behavioral Scientist 62, no. 2 (February 1, 2018): 210-28, https://doi.org/10.1177/0002764217739663; Lankford, "Identifying Potential Mass Shooters and Suicide Terrorists With Warning Signs of Suicide, Perceived Victimization, and Desires for Attention or Fame." 163 Peter DeScioli and Robert Kurzban, "A Solution to the Mysteries of Morality.," Psychological Bulletin 139, no. 2 (2013): 477-96, https://doi.org/10.1037/a0029065; Pietraszewski, "How the Mind Sees Coalitional and Group Conflict"; Tooby and Cosmides, "Groups in Mind: The Coalitional Roots of War and Morality."

164 Pietraszewski, "How the Mind Sees Coalitional and Group Conflict"; David Pietraszewski, "Towards a Computational Theory of Social Groups: A Finite Set of Cognitive Primitives for Representing Any and All Social Groups in the Context of Conflict," Behavioral and Brain Sciences, 2021, 1-62, https://doi.org/10.1017/So140525X21000583; Tooby and Cosmides, "Groups in Mind: The Coalitional Roots of War and Morality."

165 E.g., Ilardi, "Interviews With Canadian Radicals"; McCauley, "Toward a Psychology of Humiliation in Asymmetric Conflict."; Andrew Silke, "Holy Warriors: Exploring the Psychological Processes of Jihadi Radicalization," European Journal of Criminology 5, no. 1 (January 1, 2008): 99-123, https://doi.org/10.1177/1477370807084226; Shobna Sonpar, "A Potential Resource? Ex-Militants in Jammu and Kashmir:," Intervention 6, no. 2 (July 2008): 147-53, https://doi.org/10.1097/WTF.obo13e328307eeb3; Webber et al., "The Road to Extremism."

166 Abdul Aziz, Aku Melawan Teroris [I Fight Terrorists] (Solo, Indonesia: Jazeera, 2004); as cited in Milla, Faturochman, and Ancok, "The Impact of Leader-Follower Interactions on the Radicalization of Terrorists," 97.

167 Shuki J. Cohen et al., "Al-Qaeda's Propaganda Decoded: A Psycholinguistic System for Detecting Variations in Terrorism Ideology," Terrorism and Political Violence 30, no. 1 (January 2, 2018): 156, https://doi.org/10.1080/o9546553.2016.1165214.

168 Mary Beth Altier et al., "Why They Leave: An Analysis of Terrorist Disengagement Events from EightySeven Autobiographical Accounts," Security Studies 26, no. 2 (April 3, 2017): 320, https://doi.org/10.1080/09636412.2017.1280307; see also: Kate Barrelle, "Pro-Integration: Disengagement from and Life after Extremism," Behavioral Sciences of Terrorism and Political Aggression 7, no. 2 (2015): 129-42; Emma Disley et al., Individual Disengagement from Al QäidaInfluenced Terrorist Groups: A Rapid Evidence Assessment to Inform Policy and Practice in Preventing Terrorism (Rand Corporation, 2011); Fernando Reinares, "Exit From Terrorism: A Qualitative Empirical Study on Disengagement and Deradicalization Among Members of ETA," Terrorism and Political Violence 23, no. 5 (November 2011): 780-803, https://doi.org/10.1080/09546553.2011.613307.

169 Ilardi, "Interviews With Canadian Radicals," 799.

170 Reinares, "Exit From Terrorism," 791.

171 Reinares, 789.

172 Ilardi, "Interviews With Canadian Radicals," 734.

173 Omar Nasiri, Inside the Jihad: My Life with Al Qaeda (Basic Books, 2007), 44.

174 Stern, "X," 447.

175 Ilardi, "Interviews With Canadian Radicals," 799.

${ }^{176}$ Scott Atran, "The Devoted Actor: Unconditional Commitment and Intractable Conflict across Cultures," Current Anthropology 57, no. S13 (June 2016): S192-203, https://doi.org/10.1086/685495; Hammad Sheikh, Ángel Gómez, and Scott Atran, "Empirical Evidence for the Devoted Actor Model," Current Anthropology 57, no. S13 (June 2016): S204-9, https://doi.org/10.1086/686221.

177 Atran, "The Devoted Actor."

178 "Mishandling Suicide Terrorism," The Washington Quarterly 27, no. 3 (June 2004): 79-81, https://doi.org/10.1162/016366004323090269.

179 E.g., Bruce Hoffman, "Holy Terror': The Implications of Terrorism Motivated by a Religious Imperative," Studies in Conflict \& Terrorism 18, no. 4 (1995): 271-84; Arie Perliger and Ami Pedahzur, "Counter Cultures, Group Dynamics and Religious Terrorism," Political Studies 64, no. 2 (2016): 297-314.

${ }_{180}$ E.g., Sandra Baez et al., "Outcome-Oriented Moral Evaluation in Terrorists," Nature Human Behaviour 1, no. 6 (June 2017): 0118, https://doi.org/10.1038/s41562-017-0118; Sageman, Leaderless Jihad Terror Networks in the Twenty-First Century.

${ }^{181}$ Ilardi, "Interviews With Canadian Radicals."

182 Bartlett and Miller, "The Edge of Violence." 
${ }^{183}$ John Horgan et al., "Walking Away: The Disengagement and de-Radicalization of a Violent Right-Wing Extremist," Behavioral Sciences of Terrorism and Political Aggression 9, no. 2 (May 4, 2017): 6, https://doi.org/10.1080/19434472.2016.1156722.

184 Stern, "X," 445.

185 Bosi and Porta, "Micro-Mobilization into Armed Groups."

${ }^{186}$ Altier et al., "Why They Leave."

187 Altier et al.; Tore Bjorgo and John G. Horgan, Leaving Terrorism behind: Individual and Collective Disengagement (Routledge, 2008); John Horgan, "Deradicalization or Disengagement? A Process in Need of Clarity and a Counterterrorism Initiative in Need of Evaluation," Revista de Psicología Social 24, no. 2 (January 2009): 291-98, https://doi.org/10.1174/021347409788041408.

188 Altier et al., "Why They Leave."

189 Daniel Koehler, "Switching Sides: Exploring Violent Extremist Intergroup Migration Across Hostile Ideologies," Political Psychology o, no. o (2019), https://doi.org/10.1111/pops.12633.

190 E.g., Baez et al., "Outcome-Oriented Moral Evaluation in Terrorists"; Philip Baugut and Katharina Neumann, "Online Propaganda Use during Islamist Radicalization," Information, Communication \& Society 23, no. 11 (September 18, 2020): 1570-92, https://doi.org/10.1080/1369118X.2019.1594333; Randy Borum, "Radicalization into Violent Extremism II: A Review of Conceptual Models and Empirical Research," Journal of Strategic Security 4, no. 4 (2011): 37-62; Borum, "Radicalization into Violent Extremism I"; Sageman, Leaderless Jihad Terror Networks in the Twenty-First Century; Marc Sageman, Misunderstanding Terrorism (University of Pennsylvania Press, 2017); Anne Speckhard and Khapta Ahkmedova, "The Making of a Martyr: Chechen Suicide Terrorism," Studies in Conflict \& Terrorism 29, no. 5 (August 2006): 429-92, https://doi.org/10.1080/10576100600698550; David Webber and Arie W. Kruglanski, "Psychological Factors in Radicalization," in The Handbook of the Criminology of Terrorism (John Wiley \& Sons, Ltd, 2017), 33-46, https://doi.org/10.1002/9781118923986.ch2.

${ }^{191}$ Essays on Actions and Events: Philosophical Essays Volume 1.

192 In his sample, Sageman found that approximately $66 \%$ of neo-jihadi terrorists had been mobilized via their male friends. Understanding Terror Networks (Philadelphia: University of Pennsylvania Press, 2004).

193 Lankford, "Identifying Potential Mass Shooters and Suicide Terrorists With Warning Signs of Suicide, Perceived Victimization, and Desires for Attention or Fame."

194 B. Franz, "Popjihadism: Why Young European Muslims Are Joining the Islamic State," Mediterranean Quarterly 26, no. 2 (January 1, 2015): 5-20, https://doi.org/10.1215/10474552-2914484; Angel Rabasa, Eurojihad: Patterns Of Islamist Radicalization And Terrorism In Europe (New York, NY: Cambridge University Press, 2014).

195 Wolfowicz et al., “A Field-Wide Systematic Review and Meta-Analysis of Putative Risk and Protective Factors for Radicalization Outcomes."

196 "Characteristics of Jihadi Terrorists in Europe (2001-2009)," in Jihadi Terrorism and the Radicalization Challenge. European and American Experiences, ed. Rik Coolsaet (Aldershot: Ashgate, 2011), 131-44, https://www.researchgate.net/profile/Edwin_Bakker4/publication/292467374_Characteristics_of_Jiha di_terrorists_in_Europe_2001-2009/links/56e8128208ae166360e4ddc6.pdf.

197 Franz, "Popjihadism"; Rabasa, Eurojihad. Note that a low degree of integration with the wider society and strong in-group attachment might describe facilitating conditions conducive to violent extremism, however, they also characterize other ethnic communities which have not engaged in violence, such as groups that have come to be known as middleman communities (Bonacich, 1973). Members of those minorities communities act as 'middlemen' between producers and consumers (e.g., employer and employee, owner and renter) providing important economic services Bonacich.. Rather than be envious of others, such middlemen communities are often the target of other's envy Fiske, Envy up, Scorn down: How Status Divides Us.

198 "The Tribalism Index: Unlocking the Relationship Between Tribal Patriarchy and Islamist Militants," New Global Studies 6, no. 1 (January 7, 2012), https://doi.org/10.1515/1940-0004.1149.

199 E.g., Omar Ashour, "Lions Tamed? An Inquiry into the Causes of De-Radicalization of Armed Islamist Movements: The Case of the Egyptian Islamic Group," Middle East Journal 61, no. 4 (2007): 621.

200 Reinares, "Exit From Terrorism," 785.

201 "Lions Tamed?," 621.

${ }^{202}$ Post, Sprinzak, and Denny, "The Terrorists in Their Own Words"; Silke, "Holy Warriors." 
${ }^{203}$ See Glowacki and Wrangham, "Warfare and Reproductive Success in a Tribal Population"; Glowacki and Wrangham, "The Role of Rewards in Motivating Participation in Simple Warfare"; Kengo Nawata, "A Glorious Warrior in War: Cross-Cultural Evidence of Honor Culture, Social Rewards for Warriors, and Intergroup Conflict," Group Processes \& Intergroup Relations, May 15, 2019, 1368430219838615, https://doi.org/10.1177/1368430219838615.

204 Glowacki and Wrangham, "Warfare and Reproductive Success in a Tribal Population"; Haggerty and Bucerius, "Radicalization as Martialization"; Sophia Moskalenko, "Civilians into Warriors: Mechanisms of Mobilization in US Army Recruitment and Training," Dynamics of Asymmetric Conflict 3, no. 3 (November 2010): 248-68, https://doi.org/10.1080/17467586.2010.532562; Post, Sprinzak, and Denny, "The Terrorists in Their Own Words"; Silke, "Holy Warriors"; Ramón Spaaij, "Men Like Us, Boys Like Them: Violence, Masculinity, and Collective Identity in Football Hooliganism," Journal of Sport and Social Issues 32, no. 4 (November 2008): 369-92, https://doi.org/10.1177/0193723508324082.

205 E.g., Koehler, "Switching Sides"; Reinares, "Exit From Terrorism."

${ }^{206}$ See for instance laws requiring the acquisition of local language skills in countries such as Switzerland. 207 Helen Warrell, "Inside Prevent, the UK's Controversial Anti-Terrorism Programme," Financial Times, January 24, 2019, https://www.ft.com/content/a82e18b4-1ea3-11e9-b126-46fc3ad87c65, emphasis added.

${ }^{208}$ E.g., Janice Gross Stein and Ron Levi, "Testing Deterrence by Denial: Experimental Results from Criminology," Studies in Conflict \& Terrorism, June 19, 2020, 1-21, https://doi.org/10.1080/1057610X.2020.1777710. 